\title{
Fuel-cell grade hydrogen production by coupling steam reforming of ethanol and carbon
} monoxide removal

$$
\text { Bernay Cifuentes }^{1,3} \text {, Felipe Bustamante }{ }^{1} \text {, Juan A. Conesa }{ }^{2} \text { and Martha Cobo }{ }^{3 *}
$$

${ }^{1}$ Environmental Catalysis Laboratory, Department of Chemical Engineering, Universidad de Antioquia, Calle 67 No. 53 - 108, Medellín, Colombia.

${ }^{2}$ Department of Chemical Engineering, Universidad de Alicante, P.O. Box 99, Alicante E-03080, Spain.

${ }^{3}$ Energy, Materials, and Environment Laboratory, Department of Chemical Engineering, Universidad de La Sabana, Campus Universitario Puente del Común, Km. 7 Autopista Norte, Bogotá, Colombia.

*Corresponding author: Email: martha.cobo@unisabana.edu.co, Tel: +571 8615555 Ext. 25207, Fax: 5718615555 


\begin{abstract}
The integration of $\mathrm{H}_{2}$ production and purification is an essential step in the development of sustainable power generation in proton exchange membrane fuel cells. Thence, coupling of steam reforming of ethanol (SRE) and carbon monoxide removal was evaluated for further hydrogen production in fuel cells. Firstly, $\mathrm{SRE}$ on $\mathrm{RhPt} / \mathrm{CeO}_{2}-\mathrm{SiO}_{2}$ catalyst was carried out at $700{ }^{\circ} \mathrm{C}$, displaying a stable product distribution for $120 \mathrm{~h}$. Then, CO removal from the actual post-reforming stream was evaluated over several $\mathrm{AuCu} / \mathrm{CeO}_{2}$ catalysts with different $\mathrm{Au}: \mathrm{Cu}$ weight ratios (1:0, 3:1, 1:1, 1:3, and 0:1). The role of each active metal was identified: Au favors $\mathrm{CO}$ conversion by the formation of carbon intermediates, and $\mathrm{Cu}$ improves $\mathrm{CO}_{2}$ selectivity due to its redox properties. A 1:1 $\mathrm{Au}: \mathrm{Cu}$ weight ratio on the $\mathrm{AuCu} / \mathrm{CeO}_{2}$ catalyst at $210{ }^{\circ} \mathrm{C}$ favors complete $\mathrm{CO}$ removal from the post-reforming stream, achieving fuel-cell grade hydrogen production. However, $25 \%$ of $\mathrm{H}_{2}$ was loss during the $\mathrm{CO}$ removal step, which is very high compared to studies with synthetic feeds. These high $\mathrm{H}_{2}$ loss would be the result of a complex network of reactions occurring during the real post-reforming cleaning. Characterization tests allowed us to identify that $\mathrm{CeO}_{2}$, combined with the $\mathrm{Cu}$ redox properties, favors water decomposition and $\mathrm{CO}$ conversion. Likewise, catalyst reduction might favor $\mathrm{Au}-\mathrm{Cu}$ alloy formation due to the similar crystal lattice. Finally, stability tests showed that $\mathrm{Au}_{1.0} \mathrm{Cu}_{1.0} / \mathrm{CeO}_{2}$ catalyst is susceptible to rearrangement due to the cumulative oxidation of its surface during operation. Nonetheless, periodic insitu reduction treatment contributes to the $\mathrm{Au}-\mathrm{Cu}$ alloy formation and stabilization, maintaining high activity and mitigating $\mathrm{H}_{2}$ loss. Indeed, $\mathrm{Au}_{1.0} \mathrm{Cu}_{1.0} / \mathrm{CeO}_{2}$ catalyst was active for $95 \mathrm{~h}$ when reduced every $24 \mathrm{~h}$, achieving fuel-cell grade hydrogen with a minimum of $14 \% \mathrm{H}_{2}$ loss.
\end{abstract}

Keywords: Bimetallic catalysts; Ceria; CO-PROX; Methanation; Water gas shift reaction. 


\section{Introduction}

Hydrogen $\left(\mathrm{H}_{2}\right)$ is a promising fuel to develop a cleaner energy system because it can be used in fuel cells (FC) to decarbonizing simultaneously mobile and stationary applications [1]. Water, heat, and electricity are the only products in FC fed with $\mathrm{H}_{2}$. Also, this technology can be integrated with local renewable resources to improve energy efficiency and security. For instance, $\mathrm{H}_{2}$ can be obtained from fermentable biomass, which is widely present in industrial and agricultural wastes, allowing to close the $\mathrm{CO}_{2}$ cycle [2].

The general process for energy production from biomass could be divided into four stages, as shown in Figure 1. Traditionally, these stages are considered separately and information of integrating processes is still missing. Bioethanol production is well-studied and depends strongly on the kind of the biomass fermented and the purifications steps, but ethanol and water are the main products expected. In $\mathrm{H}_{2}$ production from bioethanol, steam reforming of ethanol (SRE) stands out for having higher $\mathrm{H}_{2}$ yield compared to other alternatives as partial oxidation or oxidative steam reforming [3]. Depending on the operating conditions and catalysts, SRE yields different amounts of $\mathrm{H}_{2}$, carbon monoxide (CO), carbon dioxide $\left(\mathrm{CO}_{2}\right)$, and methane $\left(\mathrm{CH}_{4}\right)$ [4]. Therefore, the purification of the $\mathrm{H}_{2}$ stream is required but the purification process depends on the end-use of $\mathrm{H}_{2}$, so this stage is usually studied independently from the SRE. Finally, FC represents a great opportunity to develop environmentally-friendly commercial devices. Among FC, proton exchange membrane FC (PEM-FC) are the most commercialized because they can operate in a wide range of temperatures with high efficiency [5], making them suitable for diverse applications. Also, recent energy and economic simulations in Aspen Plus software show the potential of coupling SRE and PEM-FC technologies [6,7]. As the presence of CO is highly undesirable in PEM-FC applications due to its deleterious effect on the cell electrodes, these studies 
include several stages to remove CO. However, an experimental study that integrates directly SRE and PEM-FC have been not reported because CO-removal is a bulky step [8]. Therefore, removal of CO from the $\mathrm{H}_{2}$ stream prior to its use in PEM-FC is a key aspect in implementing of this technology.

\section{Figure 1}

Table 1 shows the reactions that would be involved in $\mathrm{CO}$-removal from $\mathrm{H}_{2}$ streams, along with the main side-reactions. Conventionally, CO-removal from post-reforming streams is carried out by a partial conversion through water gas shift reaction (WGSR) (Eq. 1) to ensure an outlet CO content close to 2000-5000 ppm [9] -which may require two reactors-, followed by a final stage to ensure low CO (<10 ppm [10]) -which could also include several reactors-. Preferential oxidation of CO (COPROX, Eq. 2) and CO methanation (Eq. 3) are the most common methods used in the final stage [11]. Among them, CO-PROX ensures the low CO concentrations (<10 ppm) [12,13] suitable for most PEM-FC. Nevertheless, excess in $\mathrm{H}_{2}$ losses is common during the final stage by the presence of secondary reactions (Eq. 4 and 5). Therefore, the conventional $\mathrm{H}_{2}$ purification is extremely complex and bulky, limiting the application of the existing $\mathrm{H}_{2}$ production technology in mobile and small FC applications [8]. Thus, an integration of CO-removal process in the same reactor has been proposed recently [14], which would be promising for the development of new applications with PEM-FC. Accordingly, the challenge to integrate $\mathrm{H}_{2}$ production and purification lies on finding a catalytic system that ensures an elevated $\mathrm{H}_{2}$ production and a complete $\mathrm{CO}$ removal in the post-reforming streams, reducing the number of reactor units.

Table 1. Chemical reactions involved in the CO-removal of post-reforming streams 


\begin{tabular}{lll}
\hline Reaction & Description & \\
\hline $\mathrm{CO}+\mathrm{H}_{2} \mathrm{O} \rightleftharpoons \mathrm{CO}_{2}+\mathrm{H}_{2}$ & Water gas shift reaction & Eq. 1 \\
$2 \mathrm{CO}+\mathrm{O}_{2} \rightarrow 2 \mathrm{CO}_{2}$ & Preferential oxidation of $\mathrm{CO}$ & Eq. 2 \\
$\mathrm{CO}+3 \mathrm{H}_{2} \rightleftharpoons \mathrm{CH}_{4}+\mathrm{H}_{2} \mathrm{O}$ & $\mathrm{CO}$ methanation & Eq. 3 \\
$2 \mathrm{H}_{2}+\mathrm{O}_{2} \rightarrow 2 \mathrm{H}_{2} \mathrm{O}$ & $\mathrm{H}_{2}$ oxidation & Eq. 4 \\
$\mathrm{CO}_{2}+4 \mathrm{H}_{2} \rightleftharpoons \mathrm{CH}_{4}+2 \mathrm{H}_{2} \mathrm{O}$ & $\mathrm{CO}_{2}$ methanation & Eq. 5 \\
\hline
\end{tabular}

In previous works, our group designed an active and stable catalyst for the SRE by assessing different supports $\left(\mathrm{CeO}_{2}, \mathrm{ZrO}_{2}\right.$, and $\left.\mathrm{La}_{2} \mathrm{O}_{3}\right)$ [15] and $\mathrm{Rh}: \mathrm{Pt}$ ratios [16], as well as a novel mixed Ce:Si support [17]. In particular, a $\mathrm{RhPt} / \mathrm{CeO}_{2}-\mathrm{SiO}_{2}$ catalyst with 0.4 wt \% $\mathrm{Rh}, 0.4$ wt \% $\mathrm{Pt}$, and a Ce/Si molar ratio of 2 in the support yields a $\mathrm{H}_{2}$-rich stream $\left(71 \%\right.$ of $\mathrm{H}_{2}, 18 \%$ of $\mathrm{CO}, 3 \%$ of $\mathrm{CO}_{2}$, and $7 \%$ of $\mathrm{CH}_{4}$ ), making it a promising material for mobile and stationary applications. Now, it is our intention to clean this stream (i.e., remove $\mathrm{CO}$ ) to be able to connect it to a PEM-FC.

Mono- and bi-metallic $\mathrm{Au}$ and $\mathrm{Cu}$ have been reported as promising active metals in WGSR $[14,18,19]$ and CO-PROX [20]. The support also plays an important role in catalyst performance for CO removal. For example, $\mathrm{CeO}_{2}$ could be used because surface oxygen vacancies favor the adsorption of carbon species, which promote WGSR [21], CO-PROX [11], and methanation [22]. Therefore, Au-Cu supported on $\mathrm{CeO}_{2}$ has been reported as a favorable catalyst for the complete removal of $\mathrm{CO}$ in synthetic post-reforming streams (containing $\mathrm{CO}, \mathrm{H}_{2}, \mathrm{CO}_{2}$, and $\mathrm{H}_{2} \mathrm{O}$ ) [12]. However, product distribution depends strongly on temperature, feed composition, and active metal ratio [17]. Therefore, the challenge is to evaluate the CO-removal in an actual post-reforming stream and identify operational variables that promote high activity and stability, preventing $\mathrm{H}_{2}$ losses. 
This study aimed to evaluate a catalytic system for $\mathrm{CO}$-free $\mathrm{H}_{2}$ production that couples SRE and COremoval reactors, looking forward to designing an in-line catalytic system to produce electricity in PEM-FC. SRE was carried out over a $\mathrm{RhPt} / \mathrm{CeO}_{2}-\mathrm{SiO}_{2}$ catalyst previously reported [17], and $\mathrm{AuCu} / \mathrm{CeO}_{2}$ catalysts were evaluated for $\mathrm{CO}$-removal. The effect of the $\mathrm{Au}: \mathrm{Cu}$ ratio on activity and selectivity was studied. Stability tests in continuous operation were conducted in the coupled system and some strategies for catalyst reactivation were assessed. Characterization tests, such as BrunauerEmmett-Teller (BET) surface area, X-ray photoelectron spectroscopy (XPS), transmission electron microscopy (TEM), and thermogravimetric analysis (TGA) were carried out to determine possible changes on the $\mathrm{AuCu} / \mathrm{CeO}_{2}$ catalysts structure during $\mathrm{CO}$-removal from post-reforming streams.

\section{Experimental}

\subsection{Catalyst synthesis}

$\mathrm{RhPt} / \mathrm{CeO}_{2}-\mathrm{SiO}_{2}$ catalyst for $\mathrm{SRE}$ was prepared according to previous report [17]. Firstly, the $\mathrm{CeO}_{2}-$ $\mathrm{SiO}_{2}$ support was prepared by mixing $\mathrm{Ce}\left(\mathrm{NO}_{3}\right)_{3} \cdot 6 \mathrm{H}_{2} \mathrm{O}\left(99.5 \%\right.$, Alfa Aesar, USA) and $\mathrm{SiO}_{2}(\mathrm{Merck}$, Germany), using water as solvent and achieving a Ce/Si molar ratio of 2 . The support was dried at 105 ${ }^{\circ} \mathrm{C}$ for $24 \mathrm{~h}$ and calcined at $500{ }^{\circ} \mathrm{C}$ in a muffle for $4 \mathrm{~h}$. Subsequently, aqueous solutions of rhodium (III) chloride hydrate $\left(\mathrm{RhCl}_{3} \cdot \mathrm{H}_{2} \mathrm{O}\right)$ (Aldrich Chem. Co., USA) and chloroplatinic acid hexahydrate $\left(\mathrm{H}_{2} \mathrm{PtCl}_{6} \cdot 6 \mathrm{H}_{2} \mathrm{O}\right)$ (Aldrich Chem. Co., USA) were using to load $\mathrm{Rh}$ and Pt metals on the support by incipient wetness co-impregnation, achieving $0.4 \mathrm{wt} \%$ of each noble metal ( $\mathrm{Rh}$ and $\mathrm{Pt})$. The metalssupport mixture was dried at $105^{\circ} \mathrm{C}$ for $24 \mathrm{~h}$, calcined at $700{ }^{\circ} \mathrm{C}$ in a muffle for $2 \mathrm{~h}$, and sieved ensuring particle sizes between 74 and177 $\mu \mathrm{m}$. 
$\mathrm{Au}-\mathrm{Cu} / \mathrm{CeO}_{2}$ catalysts for $\mathrm{CO}$ removal were prepared with different $\mathrm{Au}: \mathrm{Cu}$ weight ratios, as shown in Table 2, by a two-step procedure. Firstly, $\mathrm{HAuCl}_{4} \cdot 3 \mathrm{H}_{2} \mathrm{O}(99.9 \%$, Sigma Aldrich, USA) was dissolved in water and the $\mathrm{pH}$ of the solution was adjusted to 6 with $\mathrm{NaOH}(0.1 \mathrm{M})$; then, $\mathrm{CeO}_{2}$ (labelled as “Ce") was added and heated to $80{ }^{\circ} \mathrm{C}$ under continuous stirring for $2 \mathrm{~h}$ [20]; the resulting slurry was filtrated, washed with water, and dried at $105^{\circ} \mathrm{C}$ for $24 \mathrm{~h}$. Afterwards, the required amount of $\mathrm{Cu}\left(\mathrm{NO}_{3}\right)_{2} \cdot 3 \mathrm{H}_{2} \mathrm{O}(99 \%$, Sigma Aldrich, USA) was used as $\mathrm{Cu}$ precursor and loaded to the previous prepared $\mathrm{Au} / \mathrm{CeO}_{2}$ catalyst by incipient wetness impregnation [23]. The total metal loading $(\mathrm{Au}+\mathrm{Cu})$ was $2 \mathrm{wt} \%$ in all catalysts. Catalysts were dried at $100^{\circ} \mathrm{C}$ for $24 \mathrm{~h}$, calcined in muffle at $500{ }^{\circ} \mathrm{C}$ for $2 \mathrm{~h}$, and sieved to ensure a particle size between 74 and $177 \mu \mathrm{m}$. These samples were labeled as "fresh" $(\mathrm{F})$ catalysts. The prepared $\mathrm{AuCu} / \mathrm{CeO}_{2}$ catalysts were represented as $\mathrm{Au}_{x} \mathrm{Cu}_{2-x} / \mathrm{Ce}(x=0,0.5,1.0,1.5$, and 2.0), where $x$ indicates Au loading (wt. \%).

Table 2. $\mathrm{AuCu} / \mathrm{CeO}_{2}$ catalysts evaluated in the $\mathrm{CO}$ removal from post-reforming streams

\begin{tabular}{|c|c|c|c|c|c|c|c|}
\hline \multirow[t]{2}{*}{ Sample $^{1,2}$} & \multirow{2}{*}{$\begin{array}{l}\mathrm{Au} \\
\text { (wt.\%) }\end{array}$} & \multirow{2}{*}{$\begin{array}{l}\mathrm{Cu} \\
\text { (wt.\%) }\end{array}$} & \multirow{2}{*}{$\begin{array}{l}\mathrm{Au}: \mathrm{Cu} \\
\text { (wt-ratio) }\end{array}$} & \multicolumn{4}{|c|}{ Weight loss of used samples $(\%)^{3}$} \\
\hline & & & & Total & $\Delta \mathrm{T} 1$ & $\Delta \mathrm{T} 2$ & $\Delta \mathrm{T} 3$ \\
\hline $\mathrm{CeO}_{2}(\mathrm{Ce})$ & - & - & - & 5.1 & 2.5 & 1.6 & 1.0 \\
\hline $\mathrm{Cu}_{2.0} / \mathrm{Ce}$ & 0 & 2.0 & $0: 1$ & 2.1 & 1.3 & 0.4 & 0.4 \\
\hline $\mathrm{Au}_{0.5} \mathrm{Cu}_{1.5} / \mathrm{Ce}$ & 0.5 & 1.5 & $1: 3$ & 1.9 & 1.4 & 0.3 & 0.2 \\
\hline $\mathrm{Au}_{1.0} \mathrm{Cu}_{1.0} / \mathrm{Ce}$ & 1.0 & 1.0 & $1: 1$ & 2.0 & 1.4 & 0.4 & 0.2 \\
\hline $\mathrm{Au}_{1.0} \mathrm{Cu}_{1.0} / \mathrm{Ce}(\mathrm{NR})$ & 1.0 & 1.0 & $1: 1$ & 4.6 & 3.6 & 0.4 & 0.6 \\
\hline $\mathrm{Au}_{1.0} \mathrm{Cu}_{1.0} / \mathrm{Ce}(\mathrm{R})$ & 1.0 & 1.0 & $1: 1$ & 2.3 & 2.0 & 0.2 & 0.1 \\
\hline $\mathrm{Au}_{1.5} \mathrm{Cu}_{0.5} / \mathrm{Ce}$ & 1.5 & 0.5 & $3: 1$ & 1.7 & 0.9 & 0.3 & 0.5 \\
\hline $\mathrm{Au}_{2.0} / \mathrm{Ce}$ & 2.0 & 0 & $1: 0$ & 1.6 & 0.8 & 0.3 & 0.5 \\
\hline
\end{tabular}

${ }^{1}$ Sub-cript in catalysts corresponds to the nominal metal loading.

${ }^{2} \mathrm{NR}$ : no reactivated sample during stability tests, and R: reactivated sample during stability test by in situ reduction cycles.

${ }^{3}$ Measured by TGA. $\Delta \mathrm{T} 1: 80-250{ }^{\circ} \mathrm{C}, \Delta \mathrm{T} 2: 250-600{ }^{\circ} \mathrm{C}$, and $\Delta \mathrm{T} 3: 600-1000{ }^{\circ} \mathrm{C}$. 


\subsection{Catalytic tests}

SRE was carried out over a $\mathrm{RhPt} / \mathrm{CeO}_{2}-\mathrm{SiO}_{2}$ catalyst in a fixed-bed reactor (ID of $12 \mathrm{~mm}$ ) at $700{ }^{\circ} \mathrm{C}$, atmospheric pressure, and under kinetic control (i.e., avoiding external and internal mass transfer limitations), according to the procedure described elsewhere [17]. The catalytic bed was made of 50 mg of $\mathrm{RhPt} / \mathrm{CeO}_{2}-\mathrm{SiO}_{2}$ and $250 \mathrm{mg}$ of inert quartz particles. $\mathrm{RhPt} / \mathrm{CeO}_{2}-\mathrm{SiO}_{2}$ catalyst was reduced insitu with $8 \% \mathrm{H}_{2} / \mathrm{N}_{2}(300 \mathrm{~mL} / \mathrm{min})$ at $700{ }^{\circ} \mathrm{C}$ for $1 \mathrm{~h}$. SRE was conducted at $6.4 \pm 0.2 \mathrm{~L}^{*} \mathrm{~g}_{\text {cat }}{ }^{-1 *} \min ^{-1}$ of space velocity $(\mathrm{SV})\left(\mathrm{GHSV}=63,500 \mathrm{~h}^{-1}\right)$ to avoid mass transfer limitations in the system. The feed was $0.03 \mathrm{~mL} / \mathrm{min}$ of synthetic bioethanol (water/ethanol with a stoichiometric molar ratio of 3). Before entering the reactor the feed was diluted in Ar to achieve 1.8 and $5.4 \mathrm{~mol} \%$ of ethanol and water, respectively, in the inlet stream. The SRE catalytic stability test was conducted for $120 \mathrm{~h}$ time-onstream (TOS) using the conditions described above. Steady state SRE product distribution was reached after $30 \mathrm{~min}$ (see Supplementary Material, Figure S1), achieving yields of $5.1 \pm 0.2$ for $\mathrm{H}_{2}, 1.3 \pm 0.2$ for $\mathrm{CO}, 0.2 \pm 0.03$ for $\mathrm{CO}_{2}$, and $0.5 \pm 0.03$ for $\mathrm{CH}_{4}$; furthermore, product distribution remained stable, indicating that SRE's product distribution over $\mathrm{RhPt} / \mathrm{CeO}_{2}-\mathrm{SiO}_{2}$ would not be a relevant variable during the CO-removal in post-reforming streams.

When the SRE's product distribution was stable (i.e., after $30 \mathrm{~min}$ ), the SRE output was directly connected to the $\mathrm{CO}$ removal reactor to carry out the catalytic evaluation of $\mathrm{CO}$ conversion in actual post-reforming streams. The effluent stream from SRE was mixed with dry air, to achieve a $\mathrm{O}_{2} / \mathrm{CO}$ molar ratio of $0.9 \pm 0.04$ in the inlet of the $\mathrm{CO}$ removal reactor: $\mathrm{O}_{2} / \mathrm{CO}$ ratio was selected based on preliminary tests (see Supplementary Material, Figure S2), where the 0.9 ratio favors the CO conversion and mitigates $\mathrm{H}_{2}$ losses, similarly to results reported by [24]. Likewise, water in post- 
reforming was not condensed because activity and selectivity were slightly improved above $180{ }^{\circ} \mathrm{C}$ by water presence (see Supplementary Material, Figure S3), in agreement with [23]. Catalytic tests were started at $300{ }^{\circ} \mathrm{C}$ and the temperature was decreased in $20^{\circ} \mathrm{C}$ intervals until $60{ }^{\circ} \mathrm{C}$ (continuous sequence, $20 \mathrm{~min}$ at each temperature) in a plug flow reactor (ID=12 mm). External and internal mass transfer limitations was controlled as reported in [17]. The catalytic bed was made of $50 \mathrm{mg}$ of catalyst sample (Au-Cu/Ce catalysts shown in Table 2) and $250 \mathrm{mg}$ of inert quartz particles. A SV of $6.5 \pm 0.2$ $\mathrm{L}^{*} \mathrm{~g}_{\mathrm{cat}}{ }^{-1 *} \min ^{-1}$ was used in the $\mathrm{CO}$ removal reactor. All catalysts samples were reduced $i n$-situ with 8 $\mathrm{mol} \% \mathrm{H}_{2} / \mathrm{Ar}$ at $300{ }^{\circ} \mathrm{C}$ for $1 \mathrm{~h}$, degassed in $\mathrm{Ar}$ at $300{ }^{\circ} \mathrm{C}$ for $30 \mathrm{~min}$, and stabilized in $10 \%$ air/ $\mathrm{Ar}$ at 300 ${ }^{\circ} \mathrm{C}$ for $30 \mathrm{~min}$. These samples were labeled as "reduced-oxidized" (R-O) catalysts. Samples used in catalytic evaluation were labeled as "used" (U) catalysts. CO-removal stability tests with several reactivation treatments were conducted on $\mathrm{Au}_{1.0} \mathrm{Cu}_{1.0} / \mathrm{Ce}$ at $210{ }^{\circ} \mathrm{C}$ for $95 \mathrm{~h}$ TOS. Specifically, reactivation treatment consisted in in-situ catalyst reduction with $8 \mathrm{~mol} \% \mathrm{H}_{2} / \mathrm{Ar}$ at $300{ }^{\circ} \mathrm{C}$ for $1 \mathrm{~h}$ at intervals of $24 \mathrm{~h}$; this treatment was selected after evaluating several methods to reactivate the catalyst (see Supplementary Material, Table S1). The sample used during the stability tests without reduction treatments was labeled as "NR", and the in-situ reduced sample as " $\mathrm{R}$ " catalyst.

The outlet products of the SRE and CO-removal reactors were measured on-line by gas chromatography (Perkin Elmer, USA). The GC was equipped with an Innowax column (30 m, 0.53 mm ID, Perkin Elmer, USA) connected to a flame ionization detector (FID) and a Carboxen 1010 plot column (30 m, $0.53 \mathrm{~mm}$ ID, Restek, USA) connected to a thermal conductivity detector (TCD), using $\mathrm{Ar}$ as carrier. This configuration allowed measuring $\mathrm{CO}, \mathrm{CO}_{2}, \mathrm{H}_{2}, \mathrm{CH}_{4}$, ethylene, and ethanol. Carbon elemental balances between inlet and outlet of each reactor were measured in all tests. 
CO conversion $\left(x_{i}\right)$ and yield for each detected product were calculated by Eqs. 6 and 7 .

$x_{i}=\frac{F_{i, \text { inlet }}-F_{i, \text { outlet } y}}{F_{i, \text { inlet } y}} * 100 \quad$ Eq. 6

Yield $_{i}=\frac{F_{i, \text { outlet } C O-\text { removal }}}{C_{\text {inlet } S R E}} \quad$ Eq. 7

Where $F_{i, \text { inlet } y}$ is the mole flow ( $\mathrm{mol} / \mathrm{min}$ ) of species $i$ (ethanol, $\mathrm{H}_{2}, \mathrm{CO}, \mathrm{CH}_{4}, \mathrm{or} \mathrm{CO}_{2}$ ) entering to the reactor $y$ (SRE or CO-removal) and $F_{i, \text { outlet } y}$ is the mole flow ( $\mathrm{mol} / \mathrm{min}$ ) of unreacted species $i$ detected by GC in the outlet of the corresponding reactor.

\subsection{Catalytic characterization}

The catalyst surface area was determined by the single-point BET surface method in a ChemBET Pulsar TPR/TPD unit (Quantachrome Instruments, Boynton Beach, FL, USA). 70 mg of samples were previously degassed in $\mathrm{He}(20 \mathrm{~mL} / \mathrm{min})$ at $120^{\circ} \mathrm{C}$ for $1 \mathrm{~h}$; surface area was measured with $30 \% \mathrm{~N}_{2} / \mathrm{He}$ (20 $\mathrm{mL} / \mathrm{min}$ ) as the adsorption gas, at liquid nitrogen temperature. The measurement was repeated until a deviation less than $5 \%$ was obtained.

XPS spectra of catalysts were obtained using an VG-Microtech Multilab electron spectrometer (Thermo-Scientific, Waltham, MA, USA) with a twin anode radiation source in the $\mathrm{Mg} \mathrm{K \alpha}(1253.6 \mathrm{eV})$ constant energy analysis mode and an energy flow of $50 \mathrm{eV}$. The analysis chamber was maintained at $5.10 \times 10^{-8} \mathrm{~Pa}$. The $\mathrm{C} 1 \mathrm{~s}$ line was set at $248.6 \mathrm{eV}$. The binding energy $(\mathrm{BE})$ values were obtained with a precision of $0.2 \mathrm{eV}$ using the Peak Fit program of the spectrometer control program. 
TEM was carried out in a JEOL JEM-2010 microscope at $200 \mathrm{kV}$ coupled to energy-dispersive X-ray spectroscopy (EDX, INCA Energy TEM100, Oxford Instruments, Abingdon, UK) with a Si(Li) detector, $30 \mathrm{~mm}^{2}$ detection area, and $142 \mathrm{eV}$ resolution. Samples were dispersed in ethanol by ultrasonic vibration and dropped on a carbon film-coated copper grid. The active metal particles were measured with ImageJ software. The mean particle diameter was calculated according to Eq. 8, where $n_{i}$ is the number of particles and $d_{i}$ is the particle diameter [25].

$\bar{d}_{p}=\frac{\sum_{i} n_{i} d_{i}^{3}}{\sum_{i} n_{i} d_{i}^{2}} \quad$ Eq. 8

TGA using a thermogravimetric analyzer (Mettler Toledo, Columbus, OH, USA) were performed to measure moisture, residues, and deposits on catalyst samples. Each sample (20 mg) was previously degassed in $\mathrm{N}_{2}(20 \mathrm{~mL} / \mathrm{min})$ at $100{ }^{\circ} \mathrm{C}$ for $1 \mathrm{~h}$ and then heated from 30 to $1000{ }^{\circ} \mathrm{C}$ in air $\left(5^{\circ} \mathrm{C} / \mathrm{min}, 100\right.$ $\mathrm{mL} / \mathrm{min}$ flow rate). Weight loss reported for used samples includes the subtraction of the weight loss obtained in R-O samples.

\section{Results and discussion}

\subsection{Activity and selectivity of $\mathrm{AuCu} / \mathrm{CeO}_{2}$ catalysts during $\mathrm{CO}$-removal}

Figure 2 shows $\mathrm{CO}$ conversion, $\mathrm{H}_{2}$ loss, and $\mathrm{CO}_{2}$ and $\mathrm{CH}_{4}$ yield over $\mathrm{AuCu} / \mathrm{Ce}$ catalysts between 60 and $300{ }^{\circ} \mathrm{C}$; the feed is the post-reforming stream. At $210^{\circ} \mathrm{C}, \mathrm{CeO}_{2}$ achieved a maximum of $55 \% \mathrm{CO}$ conversion (Figure 2a) with $15 \% \mathrm{H}_{2}$ loss (Figure 2b). Moreover, $\mathrm{CO}_{2}$ and $\mathrm{CH}_{4}$ were produced at rates

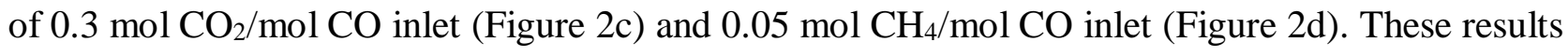
show that $\mathrm{CeO}_{2}$ mainly promoted CO-PROX (Eq. 2) with small amounts of methanation (Eq. 3 and 5). 
This behavior can be related to the support activation. In fact, $\mathrm{H}_{2}$ decomposition and methanation are favored on catalysts with a reduced surface [22]. Oppositely, $\mathrm{CO}$ adsorbed $\left(\mathrm{CO}_{\mathrm{ad}}\right)$ reacts with support's lattice oxygen available over unreduced surfaces, favoring $\mathrm{CO}$ oxidation and avoiding methanation [26]. In this work, all catalysts samples were reduced in-situ with $\mathrm{H}_{2} / \mathrm{Ar}$ for $1 \mathrm{~h}$, degassed in Ar for 30 min, and stabilized in air/Ar for 30 min. Thus, $\mathrm{CeO}_{2}$ mostly promoted CO-removal by CO-PROX, but produces small amounts of $\mathrm{CH}_{4}$ by methanation probably due to the $\mathrm{H}_{2}$ pretreatment.

\section{Figure 2.}

Catalytic performance of $\mathrm{AuCu} / \mathrm{Ce}$ catalysts with different $\mathrm{Au}: \mathrm{Cu}$ weight ratios was evaluated in $\mathrm{CO}$ removal of the post-reforming stream. A volcano-shape was observed in $\mathrm{CO}$ conversion with temperature (Figure 2a), due to the thermodynamic limitations of this reaction at high temperature. Besides, when Au loading increased, CO conversion was favored (Figure 2a) because Au is 9 times more active than $\mathrm{Cu}$ in WGSR (Eq. 1) and CO-PROX (Eq. 2) reactions [27]. Also, Au favors simultaneously $\mathrm{CO}$ and $\mathrm{O}_{2}$ adsorption, reducing the activation energy of $\mathrm{CO}$ oxidation [12], and promotes changes in the surface of the catalyst, favoring $\mathrm{CO}$ oxidation [28]. Thus, Au inclusion on $\mathrm{AuCu} / \mathrm{Ce}$ catalysts fosters $\mathrm{CO}$ removal by possible changes in the catalysts structure, as will be addressed below (“Catalysts characterization”, Section 3.3).

$\mathrm{Au}: \mathrm{Cu}$ ratio in the $\mathrm{AuCu} / \mathrm{Ce}$ catalysts also affected $\mathrm{H}_{2}$ losses, which is undesirable. Two zones were identified for $\mathrm{H}_{2}$ losses on $\mathrm{AuCu} / \mathrm{Ce}$ catalysts (Figure 2b). Between 60 and $175{ }^{\circ} \mathrm{C} \mathrm{H}_{2}$ losses increased with temperature, as expected [29]; catalysts with high $\mathrm{Au}$ content $\left(\mathrm{Au}_{2.0} / \mathrm{Ce}, \mathrm{Au}_{1.5} \mathrm{Cu}_{0.5} / \mathrm{Ce}\right.$, and $\mathrm{Au}_{1.0} \mathrm{Cu}_{1.0} / \mathrm{Ce}$ ) showed the higher $\mathrm{H}_{2}$ losses. Between 175 and $300{ }^{\circ} \mathrm{C}$, on the other hand, $\mathrm{H}_{2}$ losses tend 
to decrease, mostly on $\mathrm{Au}_{1.5} \mathrm{Cu}_{0.5} / \mathrm{Ce}$ and $\mathrm{Au}_{1.0} \mathrm{Cu}_{1.0} / \mathrm{Ce}$. Active sites for $\mathrm{CO}-\mathrm{PROX}$ on $\mathrm{Au} / \mathrm{Ce}$ is a combination of $\mathrm{Au}^{0}$ and $\mathrm{Au}^{+}-\mathrm{OH}^{-}$species [30], where $\mathrm{Au}^{0}$ activates $\mathrm{O}_{2}$ molecules and $\mathrm{OH}^{-}$groups provide the pathway for the $\mathrm{CO}_{2}$ formation, which is an effective way to remove $\mathrm{CO}$. Meanwhile, reduced $\mathrm{Cu}$ interacts directly with $\mathrm{CO}$ to form $\mathrm{CO}_{2}$, helped by the near oxygen vacancies [31], ensuring high $\mathrm{CO}_{2}$ selectivity of $\mathrm{Cu} / \mathrm{Ce}$. Thus, despite the Au mechanism is considered more effective to $\mathrm{CO}$ decomposition [27], the $\mathrm{Cu}$ mechanism could achieve lower $\mathrm{H}_{2}$ losses because it does not involve $\mathrm{H}^{*}$ species in the CO removal.

$\mathrm{CO}_{2}$ yield on $\mathrm{AuCu} / \mathrm{Ce}$ catalysts also displays different behavior with temperature, Figure 2c. Between 60 and $175^{\circ} \mathrm{C}, \mathrm{CO}_{2}$ yield increases with temperature, the change being more pronounced on $\mathrm{Cu}_{2.0} / \mathrm{Ce}$, $\mathrm{Au}_{0.5} \mathrm{Cu}_{1.5} / \mathrm{Ce}$, and $\mathrm{Au}_{1.0} \mathrm{Cu}_{1.0} / \mathrm{Ce}$. Decrease of $\mathrm{CO}_{2}$ yield at higher temperatures maybe the result of a competition between $\mathrm{CO}$ and $\mathrm{H}_{2}$ oxidation [32]. Figure $2 \mathrm{~d}$ shows that the $\mathrm{CH}_{4}$ formation is mainly promoted at intermediate temperatures $\left(110-190{ }^{\circ} \mathrm{C}\right)$, especially on $\mathrm{Au}_{2.0} / \mathrm{Ce}, \mathrm{Au}_{1.5} \mathrm{Cu}_{0.5} / \mathrm{Ce}$, and $\mathrm{Au}_{1.0} \mathrm{Cu}_{1.0} / \mathrm{Ce}$. High $\mathrm{CH}_{4}$ yield was not expected because $\mathrm{Au}$ - and $\mathrm{AuCu}$-supported catalysts are recognized to avoid methanation during CO-PROX of synthetic post-reforming stream [27]. However, Wang at al. [31] evaluated Au-supported catalysts for CO-PROX, reporting both $\mathrm{CO}$ and $\mathrm{CO}_{2}$ methanation at $160{ }^{\circ} \mathrm{C}$, with $97 \% \mathrm{CO}$ conversion on $\mathrm{Au} / \mathrm{Ce}$. Thus, $\mathrm{AuCu} / \mathrm{Ce}$ catalysts could favor methanation under certain conditions. The $\mathrm{H}_{2}$ loss profile matches that of $\mathrm{CH}_{4}$ yield (Figure $2 \mathrm{~b}$ and d). Accordingly, $\mathrm{Au}_{1.0} \mathrm{Cu}_{1.0} / \mathrm{Ce}$ catalyst showed the lower $\mathrm{H}_{2}$ losses (25\%, see Figure $2 \mathrm{~b}$ ) with complete CO conversion at $210{ }^{\circ} \mathrm{C}$ (see Figure 2a). However, $\mathrm{H}_{2}$ losses are still elevated compared to the recommended goal (<5\% [33]) for CO-PROX. Independent evaluation of WGSR, CO-PROX, COmethanation, and $\mathrm{CO}_{2}$-methanation on $\mathrm{Au}_{1.0} \mathrm{Cu}_{1.0} / \mathrm{Ce}$ catalyst (see Supplementary Material, Figure S4) revealed that $\mathrm{CO}$ removal on actual post-reforming stream is not a cumulative contribution of the CO- 
removal reactions. The high $\mathrm{CO}$ concentration and the complex network of reactions in an actual postreforming stream could favor $\mathrm{H}_{2}$ losses greater than $5 \%$. Thus, despite the high $\mathrm{H}_{2}$ loss, CO-removal of post-reforming streams on $\mathrm{Au}_{1.0} \mathrm{Cu}_{1.0} / \mathrm{Ce}$ catalyst at $210{ }^{\circ} \mathrm{C}$ ensures FC-grade $\mathrm{H}_{2}$. Therefore, stability tests were carried out to evaluate this $\mathrm{FC}$-grade $\mathrm{H}_{2}$ production, to identify the catalyst stabilization time, and to check the possible abrupt changes that could shift the behavior of the catalyst outside the narrow operation window observed in Figure 2.

\subsection{Stability of the coupled SRE/CO-removal system}

Catalysts stability and productivity are the most relevant industrial parameters [34]. So, these characteristics must be established prior to a catalyst extensive application. Thence, $\mathrm{Au}_{1.0} \mathrm{Cu}_{1.0} / \mathrm{Ce}$ catalyst was subjected to a stability tests at $210^{\circ} \mathrm{C}$. In preliminary tests (see Supplementary Material, Figure $\mathrm{S} 5), \mathrm{Au}_{1.0} \mathrm{Cu}_{1.0} / \mathrm{Ce}$ catalyst showed rapidly deactivation during $40 \mathrm{~h}$ TOS, accompanied by a high $\mathrm{CH}_{4}$ production. Thus, several reactivation treatments were carried out (see Supplementary Material, Table S1 and Figure S5). An in-situ reduction (treatment 4 in Table S1) with 8 mol\% $\mathrm{H}_{2} / \mathrm{Ar}$ stream $(300 \mathrm{~mL} / \mathrm{min})$ at $300{ }^{\circ} \mathrm{C}$ for $1 \mathrm{~h}$ followed by a degasification in $\mathrm{Ar}$ at $300{ }^{\circ} \mathrm{C}$ for $30 \mathrm{~min}$ was selected as treatment to avoid catalysts deactivation. Figure 3 shows the catalytic performance of the $\mathrm{Au}_{1.0} \mathrm{Cu}_{1.0} / \mathrm{Ce}$ catalyst undergoing the reactivation treatment every $24 \mathrm{~h}$. Complete $\mathrm{CO}$ conversion was observed when the catalysts was periodically reduced (see Figure 3a), suggesting that a reduced catalyst surface is paramount in the $\mathrm{CO}$ removal. In fact, $\mathrm{Au}-\mathrm{Cu}$ alloy formation [23] increases surface oxygen mobility [10] and improves the $\mathrm{Cu}$ redox properties [13], which are key factors to favor $\mathrm{CO}$ oxidation, whereas excessive surface oxidation by the presence of oxidants in the gas phase could quickly affect catalytic activity [10]. Thus, accumulative surface oxidation by $\mathrm{O}_{2}$ and water could reduce the catalytic activity, requiring the reduction cycles. 


\section{Figure 3}

$\mathrm{H}_{2}$ loss (e.g., conversion) are also shown in Figure $3 \mathrm{a}$. After 1 h, $\mathrm{H}_{2}$ losses decreased rapidly, achieving $9 \%$ at $9 \mathrm{~h}$, followed by increasing and decreasing intervals. However, after the first reduction treatment, $\mathrm{H}_{2}$ conversion was kept lower than $14 \%$. Bimetallic catalysts supported on $\mathrm{CeO}_{2}$ tend to experience surface rearrangements under both reducing and oxidizing atmospheres [35], affecting the catalytic performance. These rearrangements have been linked to the modification in the number of oxygen vacancies [36] which are involved in the oxidation mechanism [31]. Figure $3 \mathrm{~b}$ shows $\mathrm{CO}_{2}$ and $\mathrm{CH}_{4}$ yield with TOS and reactivation cycles. Decrease of $\mathrm{CH}_{4}$ and increase of $\mathrm{CO}_{2}$ production are observed at the same time than $\mathrm{H}_{2}$ losses decrease. Thus, methanation activity of the catalyst declined with TOS; furthermore, $\mathrm{CH}_{4}$ consumption was observed in the reduced sample, indicating that $\mathrm{CH}_{4}$ decomposition or reverse methanation could be taking place. This behavior could explain the increasing $\mathrm{CO}_{2}$ yield and the mitigation of $\mathrm{H}_{2}$ losses with TOS. Indeed, $\mathrm{CH}_{4}$ increased rapidly in N-R samples at $23 \mathrm{~h}$ TOS (see Supplementary Material, Figure S5). Caputo et al. [37] reported that the reduction process contributes to $\mathrm{Cu}$ redistribution and stabilization on $\mathrm{CuO} / \mathrm{CeO}_{2}$. Thus, TOS could favor a rearrangement on the catalyst surface, which reduces $\mathrm{CH}_{4}$ formation and $\mathrm{H}_{2}$ losses. Nonetheless, oxidant species such as $\mathrm{O}_{2}$ and water could affect the catalyst activity and selectivity, favoring a rapid deactivation. Periodic insitu reduction could mitigate this accumulative surface oxidation, achieving high activity with less $\mathrm{H}_{2}$ losses. 
In this way, BET surface area, XPS, TEM, EDX, and TGA analyses were employed to identify the changes in the catalytic structure of $\mathrm{AuCu} / \mathrm{Ce}$ catalysts resulting from $\mathrm{Au}: \mathrm{Cu}$ ratio and TOS, which would enlighten the phenomena that is occurring during the CO-removal of post-reforming streams.

\subsection{Catalysts characterization}

Possible rearrangements in the catalyst structure by the presence of $\mathrm{Cu}$ and $\mathrm{Au}$, and the operating conditions, could explain the catalytic behavior of $\mathrm{AuCu} / \mathrm{Ce}$ during the $\mathrm{CO}$ removal from postreforming streams. Thus, textural and morphological properties of $\mathrm{AuCu} / \mathrm{Ce}$ catalyst were studied by BET surface area, XPS, TEM, EDX, and TGA.

\subsubsection{BET surface area}

BET surface areas of $\mathrm{AuCu} / \mathrm{Ce}$ catalysts are shown in Figure 4. Surface area of the catalysts which were activated by reduction-oxidation (R-O) increased with $\mathrm{Cu}$ content, reaching a maximum of 84 $\mathrm{m}^{2} / \mathrm{g}_{\text {cat }}$ for $\mathrm{Cu}_{2.0} / \mathrm{Ce}$. Nagaraja et al. [38] found that the BET surface area started increasing with increase in $\mathrm{Cu}$ loading on $\mathrm{Cu} / \mathrm{MgO}$ due to the formation of $\mathrm{CuO}$, which may cause changes in the crystallinity of the support. However, the presence of a second metal in $\mathrm{Cu}$ catalysts would mitigate $\mathrm{CuO}$ formation [39]. Thus, $\mathrm{Cu}$ inclusion in $\mathrm{AuCu} / \mathrm{Ce}$ catalysts could promote changes in $\mathrm{CeO}_{2}$ crystallinity, causing an increase in their BET surface area. A direct relationship between catalytic activity and catalysts surface area was not detected in this study, but the high $\mathrm{CO}_{2}$ selectivity found in $\mathrm{Cu}$ catalysts could be attributed to their larger specific surface areas due to a higher $\mathrm{Cu}$ dispersion [40], which increased the availability of oxygen vacancies. However, BET surface area decreased after use (U samples), mostly with high $\mathrm{Cu}$ loadings $\left(\mathrm{Au}_{1.0} \mathrm{Cu}_{1.0} / \mathrm{Ce}, \mathrm{Au}_{0.5} \mathrm{Cu}_{1.5} / \mathrm{Ce}\right.$, and $\left.\mathrm{Cu}_{2.0} / \mathrm{Ce}\right)$, suggesting that these catalysts could be more susceptible to surface changes and formation of carbonaceous 
deposits with TOS. Likewise, samples used in stability tests showed a higher decreasing in surface area, especially on NR samples, which showed a 13.6\% BET area reduction. Therefore, the postreformed atmosphere could be favoring changes in the surface area of the catalyst, which could be mitigated by periodic reduction cycles.

\section{Figure 4.}

\subsubsection{XPS}

Oxidation states of the elements on $\mathrm{AuCu} / \mathrm{Ce}$ catalysts were evaluated by XPS. Figure 5 shows the XPS spectra of $\mathrm{Cu}, \mathrm{Au}$, and $\mathrm{Ce}$ in $\mathrm{AuCu} / \mathrm{Ce}$ catalysts before (R-U) and after (U) CO-removal reaction. The amount of each species was determined by integration of each characteristic peak. In R-O catalysts (see Figure 5a), three oxidation states were identified in $\mathrm{Cu} 2 \mathrm{p}_{3 / 2}: \mathrm{Cu}^{0}\left(931 \mathrm{eV}\right.$ [41]), $\mathrm{Cu}^{+}(933 \mathrm{eV}$ [42]), and $\mathrm{Cu}^{+2}$ (939 and $942 \mathrm{eV}$ [43]). Most $\mathrm{Cu}$ species corresponded to $\mathrm{Cu}^{0}$. The $\mathrm{Cu}^{0} / \mathrm{Cu}$ proportion was slightly higher in $\mathrm{Au}_{0.5} \mathrm{Cu}_{1.5} / \mathrm{Ce}(0.52)$ and $\mathrm{Au}_{1.0} \mathrm{Cu}_{1.0} / \mathrm{Ce}(0.51)$, compared to $\mathrm{Cu}_{2.0} / \mathrm{Ce}(0.46)$, indicating that $\mathrm{Au}$ favors $\mathrm{Cu}$ reduction $\left(\mathrm{Cu}\right.$ was not detected by XPS on $\mathrm{Au}_{1.5} \mathrm{Cu}_{0.5} / \mathrm{Ce}$, possibly because of the low $\mathrm{Cu}$ loading in this sample). Nonetheless, $\mathrm{Cu}^{0}$ is not an active species for $\mathrm{CO}$ oxidation [44], so its presence indicates a loss of active sites. This explains the activity decrease when the $\mathrm{Cu}$ loading increased in the catalyst (see Figure $2 \mathrm{a}$ ). In contrast, $\mathrm{Cu}^{+}$is the main active site in $\mathrm{CO}$ PROX over $\mathrm{Cu}$ catalysts as a result of its strong association with ceria $(\mathrm{Cu}-\mathrm{O}-\mathrm{Ce})$ [45] and the fact that it acts as a selective adsorption site for $\mathrm{CO}$, promoting $\mathrm{CO}_{2}$ formation [46]. Therefore, a certain amount of oxidized $\mathrm{Cu}\left(\mathrm{Cu}^{+2}\right)$ sites is necessary to inhibit $\mathrm{H}_{2}$ dissociation [46]. The $\mathrm{Cu}^{+} / \mathrm{Cu}^{+2}$ ratio in $\mathrm{AuCu} / \mathrm{Ce}$ decreased in the order: $\mathrm{Cu}_{2.0} / \mathrm{Ce}(1.2)>\mathrm{Au}_{0.5} \mathrm{Cu}_{1.5} / \mathrm{Ce}(0.9)>\mathrm{Au}_{1.0} \mathrm{Cu}_{1.0} / \mathrm{Ce}(0.7)$. Elevated amounts of $\mathrm{Cu}^{+}$species on $\mathrm{Cu}_{2.0} / \mathrm{Ce}$ and $\mathrm{Au}_{0.5} \mathrm{Cu}_{1.5} / \mathrm{Ce}$ could be linked to the superior $\mathrm{CO}_{2}$ yield of these catalysts 
(see Figure $2 \mathrm{c}$ and $\mathrm{d}$ ). However, a $\mathrm{Cu}^{+2}$ species deficiency on these catalysts could be associated with a high $\mathrm{H}_{2}$ oxidation compared to $\mathrm{Au}_{1.0} \mathrm{Cu}_{1.0} / \mathrm{Ce}$ (see Figure $2 \mathrm{~b}$ at temperatures between 170 and $255^{\circ} \mathrm{C}$ ). Thus, $\mathrm{Au}_{1.0} \mathrm{Cu}_{1.0} / \mathrm{Ce}$ seems to have the right $\mathrm{Cu}^{+} / \mathrm{Cu}^{+2}$ ratio to ensure high activity, with lower hydrogen loss.

Regarding $\mathrm{Cu}$ in $\mathrm{U}$ samples (Figure $5 \mathrm{~b}$ ), $\mathrm{Au}_{1.0} \mathrm{Cu}_{1.0} / \mathrm{Ce}$ and $\mathrm{Cu}_{2.0} / \mathrm{Ce}$ catalysts showed an increase in $\mathrm{Cu}^{0}$ and $\mathrm{Cu}^{+}$species, decreasing $\mathrm{Cu}^{+2}$ species. Even in $\mathrm{Au}_{1.0} \mathrm{Cu}_{1.0} / \mathrm{Ce}$, the decrease was so drastic that $\mathrm{Cu}^{+2}$ was not detected. Hence, these catalysts could favor high $\mathrm{CO}_{2}$ selectivity, but could be also susceptible to lose activity and promote high $\mathrm{H}_{2}$ oxidation under operation. $\mathrm{Au}_{0.5} \mathrm{Cu}_{1.5} / \mathrm{Ce}$ showed an increase in $\mathrm{Cu}^{+2}$ at the expense of $\mathrm{Cu}^{0}$ and $\mathrm{Cu}^{+}$, which would favor activity, but is undesirable for $\mathrm{CO}_{2}$ selectivity. The oxidation of $\mathrm{Cu}$ could be ascribed to the presence of oxidants as $\mathrm{O}_{2}$ and water, and the diffusion of lattice oxygen to the surface [47].

\section{Figure 5.}

Figure 5c shows XPS spectra of Au 4f for fresh, R-O samples. The characteristic peak of $\mathrm{Au}^{0}$ around $84 \mathrm{eV}$ was observed. The shift to lower $\mathrm{BE}(\sim 0.3 \mathrm{eV})$ could be associated with an increase in electron density by the presence of $\mathrm{Cu}[23] . \mathrm{Au}^{0}$ and $\mathrm{Au}^{\delta+}$ could interact with $\mathrm{CO}_{\mathrm{ad}}$, but $\mathrm{Au}^{0}-\mathrm{CO}_{\mathrm{ad}}$ species are most reactive with $\mathrm{O}_{2}$ [48]. It is expected that the $\mathrm{Au}-\mathrm{CeO}_{2}$ interaction involves a charge transfer, leading to $\mathrm{Au}$ oxidized species [49]. However, oxidized species as $\mathrm{Au}^{+}(85 \mathrm{eV}[23])$ and $\mathrm{Au}^{+3}(86 \mathrm{eV}$ [49]) were not detected, indicating that $\mathrm{Au}$ have a slight interaction with $\mathrm{CeO}_{2}$, which increases $\mathrm{Au}$ activity. In used samples (Figure 5d), no significant changes were observed and only $\mathrm{Au}^{0}$ was detected. Thus, alterations in $\mathrm{Au}$ oxidation state by operation were not identified on $\mathrm{AuCu} / \mathrm{Ce}$ catalysts. 
Figures 5e and f show XPS spectra of Ce; symbols of V and U represent the spin-orbit coupling of $3 \mathrm{~d}_{5 / 2}$ and $3 \mathrm{~d}_{3 / 2}$, respectively, associated with $\mathrm{Ce}^{+3}$ and $\mathrm{Ce}^{+4}$ species. Deconvoluted peaks of $\mathrm{V}^{0}, \mathrm{~V}^{\prime}, \mathrm{U}^{0}$, and $\mathrm{U}^{\prime}$ could be ascribed to $\mathrm{Ce}_{2} \mathrm{O}_{3}\left(\mathrm{Ce}^{+3}\right)$, while $\mathrm{V}, \mathrm{V}^{\prime \prime}, \mathrm{V}^{\prime \prime \prime}, \mathrm{U}, \mathrm{U}^{\prime \prime}$, and $\mathrm{U}^{\prime \prime \prime}$ correspond to $\mathrm{CeO}_{2}$ $\left(\mathrm{Ce}^{+4}\right)$ [50]. Ten peaks were observed in all $\mathrm{AuCu} / \mathrm{Ce}$ catalysts, indicating that $\mathrm{CeO}_{2}$ is partially reduced. Partial reduction of $\mathrm{Ce}^{+4}$ to $\mathrm{Ce}^{+3}$ generates oxygen vacancies, which dissociates $\mathrm{CO}_{2}$ into $\mathrm{CO}_{\mathrm{ad}}$ species [51], and favor oxygen mobility, which can act as an oxidizing agent [47]. Table 3 shows the relative atomic content of the main species on $\mathrm{AuCu} / \mathrm{Ce}$ catalysts. The $\mathrm{Ce}^{+3} / \mathrm{Ce}^{+4}$ ratio for $\mathrm{AuCu} / \mathrm{Ce}$ catalysts increased with $\mathrm{Cu}$ loading, which could be linked to the incorporation of $\mathrm{Cu}$ species into the lattice of $\mathrm{CeO}_{2}$ and $\mathrm{Cu}^{+}$formation [52]. Thus, high selectivity of $\mathrm{AuCu} / \mathrm{Ce}$ catalysts with high $\mathrm{Cu}$ loading could be associated to a synergetic effect of the redox characteristics of $\mathrm{Cu}$ and $\mathrm{CeO}_{2}$, which are associated to the presence of both $\mathrm{Cu}^{+}$and $\mathrm{CeO}_{2}$ oxygen vacancies. In addition, small crystal size of $\mathrm{CeO}_{2}$ is expected when vacancies increase on surface [53], which could be related to the increase in BET area with $\mathrm{Cu}$ content (Figure 4). Oxygen vacancies contribute to the $\mathrm{CO}_{2}$ decomposition and lead to the re-oxidation of $\mathrm{Cu}^{+}$and $\mathrm{Ce}^{+3}[54]$. Then, the amount of oxygen vacancies must be stable to keep the catalytic cycle. $\mathrm{Ce}^{+3} / \mathrm{Ce}^{+4}$ ratio decreased in $\mathrm{Cu}_{2.0} / \mathrm{Ce}$ and $\mathrm{Au}_{0.5} \mathrm{Cu}_{1.5} / \mathrm{Ce}$, remained constant in $\mathrm{Au}_{1.0} \mathrm{Cu}_{1.0} / \mathrm{Ce}$, and increased in $\mathrm{Au}_{2.0} / \mathrm{Ce}$ and $\mathrm{Au}_{1.5} \mathrm{Cu}_{0.5} / \mathrm{Ce}$, indicating that $\mathrm{Cu}$ promotes the oxidation of $\mathrm{CeO}_{2}$ under operation. The slight $\mathrm{Ce}^{+3}$ formation under reaction conditions could be ascribed to the reductive features of $\mathrm{Au}$ [55]. Thus, $\mathrm{Au}_{1.0} \mathrm{Cu}_{1.0} / \mathrm{Ce}$ has favorable $\mathrm{Cu}$ and $\mathrm{Au}$ loadings to promote and retain oxygen vacancies on the catalysts.

Table 3. Relative atomic content of main species on $\mathrm{AuCu} / \mathrm{Ce}$ catalysts from XPS 


\begin{tabular}{|c|c|c|c|c|c|c|c|c|c|c|c|}
\hline \multirow{2}{*}{ Catalyst } & \multicolumn{2}{|c|}{$\mathrm{Ce}^{+3} / \mathrm{Ce}^{+4}$} & \multicolumn{3}{|c|}{$\mathrm{O} / \mathrm{Ce}$} & \multicolumn{3}{|c|}{$\mathrm{Cu} / \mathrm{Ce}\left(10^{2}\right)$} & \multicolumn{3}{|c|}{$\mathrm{Au} / \mathrm{Ce}\left(10^{2}\right)$} \\
\hline & $\mathrm{R}-\mathrm{O}$ & $\mathrm{U}$ & $\mathrm{R}-\mathrm{O}$ & $\mathrm{U}$ & $\mathrm{E}$ & $\mathrm{R}-\mathrm{O}$ & $\mathrm{U}$ & $\mathrm{E}$ & $\mathrm{R}-\mathrm{O}$ & $\mathrm{U}$ & $\mathrm{E}$ \\
\hline $\mathrm{Cu}_{2.0} / \mathrm{Ce}$ & 0.9 & 0.7 & 2.2 & 3.2 & 2.0 & 10.1 & 9.2 & 5.5 & 0.0 & 0.0 & 0.0 \\
\hline $\mathrm{Au}_{0.5} \mathrm{Cu}_{1.5} / \mathrm{Ce}$ & 0.7 & 0.6 & 1.2 & 2.2 & 2.0 & 8.2 & 6.1 & 4.1 & 1.0 & 1.1 & 0.4 \\
\hline $\mathrm{Au}_{1.0} \mathrm{Cu}_{1.0} / \mathrm{Ce}$ & 0.6 & 0.6 & 2.9 & 3.7 & 2.0 & 6.1 & 2.8 & 2.7 & 1.0 & 1.2 & 0.9 \\
\hline $\mathrm{Au}_{1.0} \mathrm{Cu}_{1.0} / \mathrm{Ce}(\mathrm{NR})$ & & 0.4 & & 3.9 & & & 2.7 & & & 1.2 & \\
\hline $\mathrm{Au}_{1.0} \mathrm{Cu}_{1.0} / \mathrm{Ce}(\mathrm{R})$ & & 0.6 & & 3.3 & & & 5.9 & & & 1.2 & \\
\hline $\mathrm{Au}_{1.5} \mathrm{Cu}_{0.5} / \mathrm{Ce}$ & 0.5 & 0.7 & 2.8 & 3.6 & 2.0 & ND & ND & 1.4 & 1.1 & 1.4 & 1.3 \\
\hline $\mathrm{Au}_{2.0} / \mathrm{Ce}$ & 0.5 & 0.6 & 3.6 & 3.5 & 2.0 & 0.0 & 0.0 & 0.0 & 1.4 & 1.5 & 1.7 \\
\hline
\end{tabular}

NR: no reactivated sample during stability tests and R: reactivated sample during stability test by in situ reduction. E: expected value. ND: no detected.

Relative atomic content of $\mathrm{Cu}$ and $\mathrm{Au}$ on $\mathrm{CeO}_{2}$ surface is shows in Table 3. Higher $\mathrm{Cu}$ contents -with respect to the expected values $(\mathrm{E})$ - were observed, indicating that $\mathrm{Cu}$ was deposited preferentially on the $\mathrm{CeO}_{2}$ surface. Meanwhile, Au content on the surface of R-O samples is near to the expected value for fresh catalysts, indicating that $\mathrm{Au}$ could be adsorbed into the $\mathrm{CeO}_{2}$ bulk.

XPS of O (not shown) indicates the presence of three main species: $\mathrm{O}^{-2}$ related to the lattice oxygen in $\mathrm{CeO}_{2}$ about $529 \mathrm{eV}$, surface oxygen, and surface $\mathrm{OH}^{-}$species, both associated to the peak at $531 \mathrm{eV}$ [49]. Surface oxygen $\left(\mathrm{O}_{\mathrm{s}}\right)$ and $\mathrm{OH}^{-}$groups play an important role in the catalytic activity and selectivity. $\mathrm{O}_{\mathrm{s}}$ can react with $\mathrm{CO}$ in the gas phase or with the $\mathrm{CO}_{\mathrm{ad}}$, which are formed by decomposition of $\mathrm{CO}_{2}$ over the oxygen vacancies, to produce $\mathrm{CO}_{2}[18] . \mathrm{OH}^{-}$species are intermediates required to $\mathrm{CO}-$ PROX on Au catalysts [30]. In R-O samples, significant changes in $\mathrm{O}_{\mathrm{s}}$ and $\mathrm{OH}^{-}$species by $\mathrm{Au}: \mathrm{Cu}$ ratio were not identified and, in average, a $21 \%$ of oxygen detected corresponded to $\mathrm{O}_{\mathrm{s}}$ and $\mathrm{OH}^{-}$species. However, in used samples the amount of $\mathrm{O}_{\mathrm{s}}$ and $\mathrm{OH}^{-}$species increased, especially when the Au loading 
was higher than $1 \mathrm{wt} \%$. Also, the relative amount of oxygen on the surface increased in all catalysts after reaction (see Table 3). Au is a recognized metal to promote $\mathrm{OH}^{-}$formation [30], which could augment by water decomposition [23]. Despite the inclusion of $\mathrm{OH}^{-}$groups is considered an effective way to $\mathrm{CO}$ decomposition in CO-PROX [27], the excess in $\mathrm{OH}^{-}$species could promote high amount of carbon intermediates [56], which could be hydrogenated easily [57]. In fact, the presence of $\mathrm{OH}^{-}$ species has been linked to simultaneous WGSR and CO-methanation [57]. Therefore, the inclusion of $\mathrm{Au}$ in $\mathrm{AuCu} / \mathrm{Ce}$ catalysts could favor the formation of $\mathrm{OH}^{-}$species under reaction conditions, which increases the activity but could also affect the selectivity by hydrogenated carbon intermediates.

After TOS, NR sample (Table 3) shows an increase of the relative abundances of $\mathrm{Cu}^{0}$ and $\mathrm{Cu}^{+2}$ by 2 and $14 \%$, respectively, meanwhile $\mathrm{Cu}^{+}$decreases by $19 \%$ with respect to the $\mathrm{R}-\mathrm{O}$ sample. These changes could explain the drastic reduction in selectivity observed after $23 \mathrm{~h}$ TOS over this samples and the deactivation after $40 \mathrm{~h}$ TOS (see Supplementary Material, Figure S5). Increase in $\mathrm{Cu}^{+2}$ species could be associated with an accumulative surface oxidation during operation [47]. In R sample, relative abundances of $\mathrm{Cu}^{+}$and $\mathrm{Cu}^{+2}$ increased by 24 and $7 \%$, respectively, meanwhile $\mathrm{Cu}^{0}$ decreased $14 \%$ respect to the $\mathrm{R}-\mathrm{O}$ sample. Increase in $\mathrm{Cu}^{+}$and $\mathrm{Cu}^{+2}$ could simultaneously mitigate both $\mathrm{H}_{2}$ oxidation and $\mathrm{CH}_{4}$ formation, reducing $\mathrm{H}_{2}$ loss, as observed in Figure $3 \mathrm{a} . \mathrm{H}_{2}$ pretreatment reduces $\mathrm{Cu}$ species [47], which could be undergoing subsequent partial oxidation during reaction. Thus, the in-situ reduction-oxidation pre-treatment proposed in this work could balance the amount of $\mathrm{Cu}^{0}, \mathrm{Cu}^{+}$, and $\mathrm{CuO}_{\mathrm{x}}$ species on the catalyst.

Changes in Au oxidation states between R-O and samples evaluated in stability tests (NR and R) were not detected. $\mathrm{Ce}^{+3} / \mathrm{Ce}^{+4}$ of NR decreased $33 \%$ while remained constant in R sample respect to R-O 
sample (Table 3). Decrease in $\mathrm{Ce}^{+3} / \mathrm{Ce}^{+4}$ is associated with the reduction of oxygen vacancies, indicating that catalytic surface is slightly being oxidized with TOS. Also, a loss in the number of oxygen vacancies could affect the activity, because of the modification of the catalyst capacity to oxidize [47]. Therefore, TOS could be promoting accumulative oxidation of the catalytic surface by the presence of oxidating species, reducing $\mathrm{Cu}^{+}$and oxygen vacancies species, which are necessary for $\mathrm{CO}$ oxidation. However, proposed reduction cycles could avoid excessive surface oxidation, favoring high activity and improving selectivity.

\subsubsection{TEM}

Figure 6 shows the TEM micrographs and particle size distribution of $\mathrm{AuCu} / \mathrm{Ce}$ catalysts. The average particle sizes obtained from the TEM analysis are listed in Table 4. As $\mathrm{Cu}$ may form irregular, highly dispersed particles [37], it was not clearly identified in TEM micrographs; moreover, there is not enough contrast between active particles and support. In R-O samples, average active particle diameter of $\mathrm{Au}$ increased with $\mathrm{Cu}$ loading, suggesting that $\mathrm{Cu}$ promotes $\mathrm{Au}$ agglomeration or alloy formation. Laguna et al. [12] reported that the presence of $\mathrm{Cu}^{+2}$ segregated on the surface avoids $\mathrm{Au}$ sintering. An appreciable amount of $\mathrm{Cu}^{+2}$ species were identified by XPS; so, the increase in active particles by the $\mathrm{Cu}$ presence could be ascribed to an alloy formation. In used samples (U), average active particle diameter increased with respect to R-O samples. This change is more significant when $\mathrm{Cu}$ loading decreased, which could be associated with Au enrichment on the surface, observed by XPS.

\section{Figure 6.}


On the other hand, interaction between active metals and support could be assessed by the evaluation of interplanar distances [17]. The typical interplanar distance of $0.30 \mathrm{~nm}$ associated to $\mathrm{CeO}_{2}$ (100) and $0.27 \mathrm{~nm}$ to $\mathrm{CeO}_{2}(111)[58,59]$ were identified in all $\mathrm{AuCu} / \mathrm{Ce}$ samples (see Figure 6a, b, and c). These configurations have been linked to the formation of $\mathrm{OH}^{-}$from water dissociation and the reduction of $\mathrm{Ce}^{+4}$ to $\mathrm{Ce}^{+3}[60]$. Thus, the high $\mathrm{O}_{\mathrm{s}}$ and $\mathrm{OH}^{-}$species density on the surface of used $\mathrm{AuCu} / \mathrm{Ce}$ catalysts detected by XPS may be the result of water decomposition on $\mathrm{CeO}_{2}$. Interplanar sizes of 0.18 and 0.24 nm correspond to $\mathrm{Cu}$ (111) and $\mathrm{Cu}$ (200) [61]. Also, Wanget al. [62] linked $0.30 \mathrm{~nm}$ distance to $\mathrm{Cu}_{2} \mathrm{O}$ $\left(\mathrm{Cu}^{+}\right)$formation, which matches with $\mathrm{Cu}$ XPS spectra. However, this value is the same of the interplanar distance of $\mathrm{CeO}_{2}(100)$, thus it was not possible to establish a clear difference between the two configurations by TEM. $\mathrm{Cu}(111)$ and $\mathrm{Cu}$ (200) configurations were identified in all samples (R-O, $\mathrm{U}, \mathrm{NR}$, and $\mathrm{R}$ ), as presented in Table 4. $\mathrm{Cu}$ (111) promotes the adsorption of $\mathrm{H}_{2} \mathrm{O}$ without dissociation, mitigating $\mathrm{OH}^{-}$formation but also favoring oxidation of $\mathrm{CO}_{\mathrm{ad}}$ to $\mathrm{CO}_{2}$ [18]. For $\mathrm{Au}$, spacing of 0.236 $\mathrm{nm}$ has been reported by (111) lattice planes [62]. Similar interplanar distance and configuration of $\mathrm{Cu}$ and $\mathrm{Au}$ could promote alloys. Au-Cu alloy formation could have interplanar spaces between 0.19 and $0.23 \mathrm{~nm}$ [23], which were observed in bimetallic $\mathrm{AuCu} / \mathrm{Ce}$ catalysts (see Figure 6b), indicating a possible $\mathrm{Au}-\mathrm{Cu}$ alloy formation on bimetallic $\mathrm{AuCu} / \mathrm{Ce}$ catalysts. Bracey et al. [63] suggested the $\mathrm{Au}-$ $\mathrm{Cu}$ alloy formation and stabilization requires a reduction treatment. Therefore, $\mathrm{H}_{2}$ pretreatment could favor the $\mathrm{Au}-\mathrm{Cu}$ alloy formation in bimetallic $\mathrm{AuCu} / \mathrm{Ce}$ samples, which could be related to changes in activity and product distribution in the bimetallic samples compared to the monometallic ones (Figure 2).

Table 4. Morphological characteristics of $\mathrm{AuCu} / \mathrm{Ce}$ catalysts obtained from TEM 


\begin{tabular}{|c|c|c|c|c|c|}
\hline \multirow[t]{2}{*}{ Catalysts } & \multicolumn{2}{|c|}{$\begin{array}{c}\text { Metal average } \\
\text { surface-area-weighted } \\
\text { diameter }\left(\mathrm{d}_{\mathrm{p}}, \mathrm{nm}\right)^{\mathrm{a}} \\
\end{array}$} & \multicolumn{2}{|c|}{$\begin{array}{l}\text { Metal dispersion } \\
(\%)^{\mathrm{b}}\end{array}$} & \multirow[t]{2}{*}{ Interplanar sizes (nm) } \\
\hline & $\mathrm{R}-\mathrm{O}$ & $\mathrm{U}$ & $\mathrm{R}-\mathrm{O}$ & $\mathrm{U}$ & \\
\hline $\mathrm{Cu}_{2.0} / \mathrm{Ce}$ & - & - & - & - & $0.18,0.24,0.25,0.27,0.30,0.34$ \\
\hline $\mathrm{Au}_{0.5} \mathrm{Cu}_{1.5} / \mathrm{Ce}$ & 4.87 & 4.78 & 22.6 & 23.0 & $0.18,0.21,0.24,0.27,0.30,0.31$ \\
\hline $\mathrm{Au}_{1.0} \mathrm{Cu}_{1.0} / \mathrm{Ce}$ & 4.85 & 5.07 & 22.9 & 21.7 & $0.19,0.20,0.21,0.25,0.27,0.30$ \\
\hline $\mathrm{Au}_{1.0} \mathrm{Cu}_{1.0} / \mathrm{Ce}(\mathrm{NR})$ & 4.85 & 5.6 & 22.9 & 19.0 & $0.19,0.20,0.21,0.25,0.27,0.30$ \\
\hline $\mathrm{Au}_{1.0} \mathrm{Cu}_{1.0} / \mathrm{Ce}(\mathrm{R})$ & 4.85 & 5.2 & 22.9 & 25.2 & $0.19,0.20,0.21,0.25,0.27,0.30$ \\
\hline $\mathrm{Au}_{1.5} \mathrm{Cu}_{0.5} / \mathrm{Ce}$ & 4.66 & 4.96 & 23.7 & 25.2 & $0.20,0.21,0.24,0.27,0.30,0.31$ \\
\hline $\mathrm{Au}_{2.0} / \mathrm{Ce}$ & 4.40 & 5.22 & 25.0 & 21.1 & $0.24,0.23,0.30,0.31,0.34$ \\
\hline
\end{tabular}

${ }^{\mathrm{a}}$ Obtained from TEM. ${ }^{\mathrm{b}}$ Metal dispersion defined as $1.1 / \mathrm{d}_{\mathrm{s}}[64] .{ }^{\mathrm{c}}$ Measured by TEM.

\subsubsection{TGA}

The amount of adsorbed and deposited species was evaluated by TGA. Table 2 shows the weight loss of used samples. To facilitate the analysis, the results were separated into three temperature regions: $\Delta \mathrm{T} 1: 80-250{ }^{\circ} \mathrm{C}$ for the loss of water and volatile compounds; $\Delta \mathrm{T} 2: 250-600{ }^{\circ} \mathrm{C}$ for less stable deposits; and, $\Delta \mathrm{T} 3: 600-1000{ }^{\circ} \mathrm{C}$ for more stable ones. $\mathrm{CeO}_{2}$ showed the highest weight loss in all intervals, indicating that the support is susceptible to adsorb species and promote carbon deposition during operation. Active metals $(\mathrm{Cu}$ and $\mathrm{Au})$ reduced this weight loss, stressing their role to avoid deactivation. Mitigation of stable deposits is most significant in bimetallic $\mathrm{Au}_{0.5} \mathrm{Cu}_{1.5} / \mathrm{Ce}$ and $\mathrm{Au}_{1.0} \mathrm{Cu}_{1.0} / \mathrm{Ce}$. The presence of possible $\mathrm{Au}-\mathrm{Cu}$ alloys in theses samples, as discussed above, contributed to mitigate carbonaceous species [23]. The presence of carbon intermediates favors surface carbon during CO-PROX [65]. As discussed in previous sections, carbon intermediates were favored by $\mathrm{OH}^{-}$species, which are formed on $\mathrm{CeO}_{2}$ and $\mathrm{Au}$. Thus, $\mathrm{OH}^{-}$groups could contribute to the excess of carbon intermediates which could be hydrogenated to produce $\mathrm{CH}_{4}$ or carbonaceous deposits. In NR sample, the amount of stable deposits increased drastically compared to U sample, which could be 
related to the deactivation observed in this sample during stability test (see Figure S-5 in Supplementary Material). In contrast, $\mathrm{R}$ samples showed less deposits compared to U samples. $\mathrm{Au}-\mathrm{Cu}$ alloy formation and stabilization under reduction cycles [63] could contribute to mitigate carbon deposition [23]. Therefore, stabilization of $\mathrm{Au}-\mathrm{Cu}$ alloys by reduction treatment are required to avoid deactivation by deposits, which stems from carbon intermediates formed on $\mathrm{CeO}_{2}$ and $\mathrm{Au}$.

\section{Conclusions}

$\mathrm{CO}$ removal in an actual post-reforming stream over $\mathrm{AuCu} / \mathrm{CeO}$ catalysts with different $\mathrm{Au}: \mathrm{Cu}$ ratios was investigated. Post-forming composition remained constant due to the stable $\mathrm{RhPt} / \mathrm{CeO}_{2}-\mathrm{SiO}_{2}$ catalyst used during the SRE. This stream was subjected to the CO catalytic cleaning. It was found that Au presence in the $\mathrm{AuCu} / \mathrm{CeO}_{2}$ catalyst favors $\mathrm{CO}$ conversion, but affects $\mathrm{CO}_{2}$ selectivity. $\mathrm{Au}_{1.0} \mathrm{Cu}_{1.0} / \mathrm{Ce}$ catalyst showed the lowest $\mathrm{H}_{2}$ lose $(25 \%)$ with total $\mathrm{CO}$ elimination at $210{ }^{\circ} \mathrm{C}$. However, $\mathrm{H}_{2}$ loss is higher than that reported for synthetic feeds because a complex network of reactions is present in the real post-reforming stream cleaning.

Characterization tests allowed to identify that $\mathrm{CeO}_{2}$ promotes $\mathrm{OH}^{-}$formation from water and interacts mainly with $\mathrm{Cu}$ trough a synergetic effect of the redox properties. Au favors both, $\mathrm{H}_{2}$ adsorption and $\mathrm{OH}^{-}$formation, improving the catalytic activity. While $\mathrm{Cu}$ increases the catalyst surface area and promotes $\mathrm{CO}_{2}$ formation, increasing the selectivity of catalysts. Likewise, the similar crystal lattice of $\mathrm{Au}$ and $\mathrm{Cu}$ could favor $\mathrm{Au}-\mathrm{Cu}$ alloy formation, especially under reducing atmospheres. Also, an excess of carbon intermediates by $\mathrm{OH}^{-}$presence, which are formed on $\mathrm{Au}$, and a high $\mathrm{CO}$ concentration in post-reforming streams was responsible for both undesirable $\mathrm{CH}_{4}$ formation and the presence of stable deposits on the catalyst. Finally, stability tests showed that $\mathrm{Au}_{1.0} \mathrm{Cu}_{1.0} / \mathrm{CeO}_{2}$ catalyst is susceptible to 
rearrangement and cumulative surface oxidation during operation. Moreover, periodic in situ reduction treatment contributes to the $\mathrm{Au}-\mathrm{Cu}$ alloy formation and stabilization, maintaining high activity and reducing $\mathrm{H}_{2}$ loss with time. $\mathrm{Au}_{1.0} \mathrm{Cu}_{1.0} / \mathrm{Ce}$ catalyst was active for $95 \mathrm{~h} \mathrm{TOS}$, when is reduced every 24 h, achieving fuel-cell grade hydrogen with a minimum of $14 \% \mathrm{H}_{2}$ loss. However, $\mathrm{H}_{2}$ loss by oxidation and methanation is still high. Thus, currently modification in the composition and synthesis method of the catalysts are being planned to achieve complete $\mathrm{CO}$ removal and $\mathrm{H}_{2}$ loss below $5 \%$.

\section{Acknowledgments}

The authors are grateful to Colciencias (Francisco Jose de Caldas Found) and Universidad de La Sabana for the financial support of this work through the Project ING-163 (Colciencias contract 1742016). The authors also acknowledge Universidad de Antioquia and Universidad de Alicante for their support to this project. B. Cifuentes acknowledges Colciencias for the doctoral scholarship (grant number 727-2015).

\section{Author contributions}

This work was developed in equal parts by Bernay Cifuentes, Felipe Bustamante, and Martha Cobo. Juan A. Conesa participated in the characterization of $\mathrm{Au}-\mathrm{Cu} / \mathrm{CeO}_{2}$ catalysts through performing techniques such as TEM, EDX, and XPS. Nevertheless, all the authors contributed to the writing and review of this document.

\section{Conflicts of interest}

There are no conflicts of interest to declare. 


\section{References}

[1] N.P. Brandon, Z. Kurban, Philos. Trans. R. Soc. London A Math. Phys. Eng. Sci. 375 (2017).

[2] R. Roldán, Int. J. Hydrogen Energy. 40 (2015) 2035-2046.

[3] W. Cai, F. Wang, E. Zhan, A. Vanveen, C. Mirodatos, W. Shen, J. Catal. 257 (2008) 96-107.

[4] D. Zanchet, J.B.O. Santos, S. Damyanova, J.M.R. Gallo, J.M. C. Bueno, ACS Catal. 5 (2015) $3841-3863$.

[5] U. Lucia, Renew. Sustain. Energy Rev. 30 (2014) 164-169.

[6] U. Gardemann, M. Steffen, A. Heinzel, Int. J. Hydrogen Energy. 39 (2014) 18135-18145.

[7] I. Rossetti, M. Compagnoni, M. Torli, Chem. Eng. J. 281 (2015) 1036-1044.

[8] T. V. Choudhary, D.W. Goodman, Catal. Today. 77 (2002) 65-78.

[9] R.J. Farrauto, Chem. Eng. J. 238 (2014) 172-177.

[10] L. Ilieva, P. Petrova, G. Pantaleo, R. Zanella, L.F. Liotta, V. Georgiev, et al., Appl. Catal. B Environ. 188 (2016) 154-168.

[11] O. Pozdnyakova, D. Teschner, A. Wootsch, J. Kröhnert, B. Steinhauer, J. Catal. 237 (2006) 116.

[12] O.H. Laguna, W.Y. Hernández, G. Arzamendi, L.M. Gandía, M. a. Centeno, J. a. Odriozola, Fuel. 118 (2014) 176-185.

[13] Q. Zhang, L. Shore, R.J. Farrauto, Int. J. Hydrogen Energy. 37 (2012) 10874-10880.

[14] T.R. Reina, S. Ivanova, O.H. Laguna, M.A. Centeno, J.A. Odriozola, Appl. Catal. B Environ. 
197 (2016) 67-72.

[15] B. Cifuentes, M.F. Valero, J. a. J. Conesa, M. Cobo, Catalysts. 5 (2015) 1872-1896.

[16] B. Cifuentes, M. Figueredo, M. Cobo, Catalysts. 7 (2017) 15.

[17] B. Cifuentes, M. Hernández, S. Monsalve, M. Cobo, Appl. Catal. A Gen. 523 (2016) 283-293.

[18] O. Jakdetchai, T. Nakajima, J. Mol. Struct. THEOCHEM. 619 (2002) 51-58.

[19] C. Ratnasamy, J.P. Wagner, Catal. Rev. 51 (2009) 325-440.

[20] L.F. Córdoba, A. Martínez-Hernández, Int. J. Hydrogen Energy. 40 (2015) 16192-16201.

[21] N.K. Gamboa-Rosales, J.L. Ayastuy, M.P. González-Marcos, M.A. Gutiérrez-Ortiz, Catal. Today. 176 (2011) 63-71.

[22] D.C. Upham, A.R. Derk, S. Sharma, H. Metiu, E.W. McFarland, T. Onishi, et al., Catal. Sci. Technol. 5 (2015) 1783-1791.

[23] X. Liao, W. Chu, X. Dai, V. Pitchon, Appl. Catal. B Environ. 142-143 (2013) 25-37.

[24] Y. Choi, H.G. Stenger, J. Power Sources. 129 (2004) 246-254.

[25] N. Krishnankutty, M.A. Vannice, J. Catal. 155 (1995) 312-326.

[26] H.-H. Liu, Y. Wang, A.-P. Jia, S.-Y. Wang, M.-F. Luo, J.-Q. Lu, Appl. Surf. Sci. 314 (2014) $725-734$.

[27] J. da S.L. Fonseca, H.S. Ferreira, N. Bion, L. Pirault-Roy, M. do C. Rangel, D. Duprez, et al., Catal. Today. 180 (2012) 34-41.

[28] T.R. Reina, C. Megías-Sayago, A.P. Florez, S. Ivanova, M.Á. Centeno, J.A. Odriozola, J. Catal. 
326 (2015) 161-171.

[29] X. Chen, J.J. Delgado, J.M. Gatica, S. Zerrad, J.M. Cies, S. Bernal, J. Catal. 299 (2013) 272283.

[30] T. Sakwarathorn, A. Luengnaruemitchai, S. Pongstabodee, J. Ind. Eng. Chem. 17 (2011) $747-$ 754.

[31] H. Wang, H. Zhu, Z. Qin, G. Wang, F. Liang, J. Wang, Catal. Commun. 9 (2008) 1487-1492.

[32] H.C. Lee, D.H. Kim, Catal. Today. 132 (2008) 109-116.

[33] R.J.B. M. J. Kahlich, H.A. Gasteiget, Iournal New Mater. Electrochem. Syst. 1 (1998) 39-46.

[34] P. Lanzafame, G. Centi, S. Perathoner, Catal. Today. 234 (2014) 2-12.

[35] N.J. Divins, I. Angurell, C. Escudero, V. Pérez-Dieste, J. Llorca, Science (80-. ). 346 (2014) $620-623$.

[36] M. Ozawa, M. Haneda, M. Hattori, IOP Conf. Ser. Mater. Sci. Eng. 18 (2011) 182010.

[37] T. Caputo, L. Lisi, R. Pirone, G. Russo, Appl. Catal. A Gen. 348 (2008) 42-53.

[38] B.M. Nagaraja, A.H. Padmasri, B. David Raju, K.S. Rama Rao, J. Mol. Catal. A Chem. 265 (2007) 90-97.

[39] J. Chen, W. Li, R. Shen, Korean J. Chem. Eng. 33 (2016) 500-506.

[40] G. Landi, P.S. Barbato, A. Di Benedetto, L. Lisi, Appl. Catal. B Environ. 181 (2016) 727-737.

[41] J. Deng, L. Zhang, H. Dai, H. He, C.T. Au, Appl. Catal. B Environ. 89 (2009) 87-96.

[42] V. Hayez, A. Franquet, A. Hubin, H. Terryn, Surf. Interface Anal. 36 (2004) 876-879. 
[43] E.B. Fox, A.F. Lee, K. Wilson, C. Song, Top. Catal. 49 (2008) 89-96.

[44] M. Tada, R. Bal, X. Mu, R. Coquet, S. Namba, Y. Iwasawa, Chem. Commun. (Camb). 2 (2007) 4689-4691.

[45] E. Moretti, M. Lenarda, L. Storaro, A. Talon, R. Frattini, S. Polizzi, et al., Appl. Catal. B Environ. 72 (2007) 149-156.

[46] C.S. Polster, H. Nair, C.D. Baertsch, J. Catal. 266 (2009) 308-319.

[47] S. Poulston, P.M. Parlett, P. Stone, M. Bowker, Surf. Interface Anal. 24 (1996) 811-820.

[48] S. Chen, L. Luo, Z. Jiang, W. Huang, ACS Catal. 5 (2015) 1653-1662.

[49] S. Zhang, X. Li, B. Chen, X. Zhu, C. Shi, A. Zhu, ACS Catal. (2014).

[50] D.M. Gu, Y.Y. Chu, Z.B. Wang, Z.Z. Jiang, G.-P. Yin, Y. Liu, Appl. Catal. B Environ. 102 (2011) 9-18.

[51] E.J. Choi, Y.H. Lee, D.W. Lee, D.J. Moon, K.Y. Lee, Mol. Catal. 434 (2017) 146-153.

[52] J. Wang, L. Zhong, J. Lu, R. Chen, Y. Lei, K. Chen, et al., 443 (2017) 241-252.

[53] G.W. Graham, W.H. Weber, C.R. Peters, R. Usmen, J. Catal. 130 (1991) 310-313.

[54] X. Gong, B. Liu, B. Kang, G. Xu, Q. Wang, C. Jia, et al., Mol. Catal. 436 (2017) 90-99.

[55] J.A. Hernández, S.A. Gómez, T.A. Zepeda, J.C. Fierro-González, G.A. Fuentes, ACS Catal. 5 (2015) 4003-4012.

[56] X. Wang, J.A. Rodriguez, J.C. Hanson, D. Gamarra, A. Martínez-Arias, M. Fernández-García, et al., J. Phys. Chem. B. 110 (2006) 428-434. 
[57] S.H. Kim, S.W. Nam, T.H. Lim, H.I. Lee, Appl. Catal. B Environ. 81 (2008) 97-104.

[58] E.M. Slavinskaya, R.V. Gulyaev, A.V. Zadesenets, O.A. Stonkus, V.I. Zaikovskii, Y. V. Shubin, et al., Appl. Catal. B Environ. 166-167 (2015) 91-103.

[59] J. Malleshappa, H. Nagabhushana, B.D. Prasad, S.C. Sharma, Y.S. Vidya, K.S. Anantharaju, Opt. - Int. J. Light Electron Opt. 127 (2016) 855-861.

[60] D.R. Mullins, P.M. Albrecht, T.-L. Chen, F.C. Calaza, M.D. Biegalski, H.M. Christen, et al., J. Phys. Chem. C. 116 (2012) 19419-19428.

[61] C. Ping, F. Li, Z. Jian, J. Wei, Propellants, Explos. Pyrotech. 31 (2006) 452-455.

[62] Z. Wang, S. Zhao, S. Zhu, Y. Sun, M. Fang, CrystEngComm. 13 (2011) 2262.

[63] C.L. Bracey, P.R. Ellis, G.J. Hutchings, Chem. Soc. Rev. 38 (2009) 2231.

[64] R.M. Heck, R.J. Farrauto, S.T. Gulati, Third Edit, Wiley, 2009.

[65] G. Marbán, I. López, T. Valdés-Solís, Appl. Catal. A Gen. 361 (2009) 160-169. 


\section{Figures caption}

Figure 1. The general process for energy production from biomass

Figure 2. (a) $\mathrm{CO}$ conversion, (b) $\mathrm{H}_{2}$ loss, (c) $\mathrm{CO}_{2}$ and (d) $\mathrm{CH}_{4}$ yield for $\mathrm{CO}$ removal of a postreforming stream on $\mathrm{AuCu} / \mathrm{CeO}_{2}$ catalysts. Inlet stream: $7.8 \% \mathrm{H}_{2}, 2.0 \% \mathrm{CO}, 0.5 \% \mathrm{CO}_{2}, 0.3 \% \mathrm{CH}_{4}$, $1.4 \% \mathrm{H}_{2} \mathrm{O}, 1.8 \% \mathrm{O}_{2}, 6.8 \% \mathrm{~N}_{2}$, and $79.4 \%$ Ar. Total metal loading $(\mathrm{Au}+\mathrm{Cu})=2 \mathrm{wt} \%$ in all catalysts.

Figure 3: (a) $\mathrm{CO}$ and $\mathrm{H}_{2}$ conversion, and (c) $\mathrm{CO}_{2}$ and (d) $\mathrm{CH}_{4}$ yield during the $\mathrm{CO}$ removal of a postreforming stream over $\mathrm{Au}_{1.0} \mathrm{Cu}_{1.0} / \mathrm{Ce}$ catalysts. Intel stream: $7.8 \% \mathrm{H}_{2}, 2.0 \% \mathrm{CO}, 0.5 \% \mathrm{CO}_{2}, 0.3 \% \mathrm{CH}_{4}$, $1.4 \% \mathrm{H}_{2} \mathrm{O}, 1.8 \% \mathrm{O}_{2}, 6.8 \% \mathrm{~N}_{2}$, and 79.4\% Ar. Reaction conditions: $\mathrm{SV}=6.5 \pm 2 \mathrm{~L}^{*} \mathrm{~g}_{\mathrm{cat}}{ }^{-1} * \mathrm{~min}^{-1} ; 50 \mathrm{mg}$ of catalyst and $250 \mathrm{mg}$ of inert quartz; $210{ }^{\circ} \mathrm{C}$. Vertical lines show reactivation treatments every $24 \mathrm{~h}$ with an in-situ reduction with $8 \mathrm{~mol} \% \mathrm{H}_{2} / \mathrm{Ar}(300 \mathrm{~mL} / \mathrm{min})$ at $300{ }^{\circ} \mathrm{C}$ for $1 \mathrm{~h}$ followed by degassing in Ar at $300{ }^{\circ} \mathrm{C}$ for $30 \mathrm{~min}$.

Figure 4. BET surface area of $\mathrm{AuCu} / \mathrm{CeO}_{2}$ catalyst samples: after reduction-oxidation(R-O), use (U), stability without in-situ reduction treatment (NR), and stability with in-situ reduction treatment (R).

Figure 5. XPS spectra of $\mathrm{Cu} 2 \mathrm{p}(\mathrm{a}$ and b), $\mathrm{Au} 4 \mathrm{f}$ ( $\mathrm{c}$ and d), and Ce $3 \mathrm{~d}$ (e and f) for reduced-oxidized (RO) and used (U) samples of $\mathrm{AuCu} / \mathrm{CeO}_{2}$ catalysts.

Figure 6. TEM images of reduced-oxidized (a) $\mathrm{Cu}_{2.0} / \mathrm{Ce}$, (b) $\mathrm{Au}_{1.0} \mathrm{Cu}_{1.0} / \mathrm{Ce}$, and (c) $\mathrm{Au}_{2.0} / \mathrm{Ce}$ catalysts, and (d-g) particle size distribution histograms for reduced-oxidized and used $\mathrm{AuCu} / \mathrm{CeO}_{2}$ catalysts. 


\section{Figures}

\section{(1) Bioethanol production}

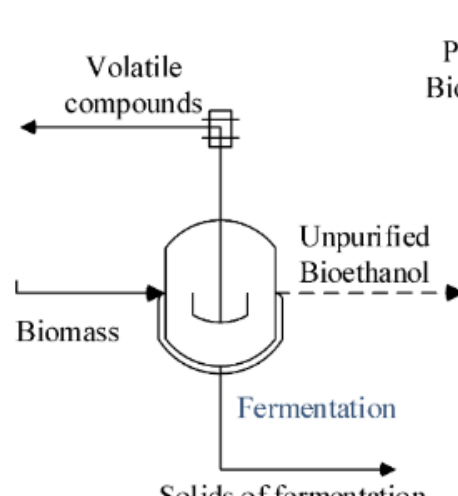

Solids of fermentation

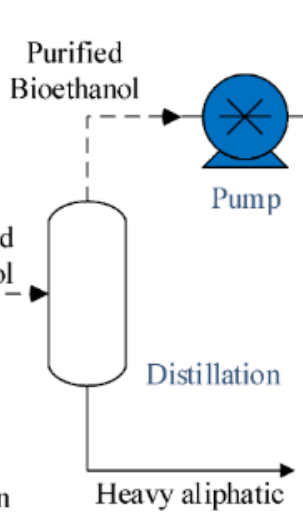

(2) Hydrogen production

Carrier (Ar)
(3) Hydrogen purification

(4) Power generation

Air

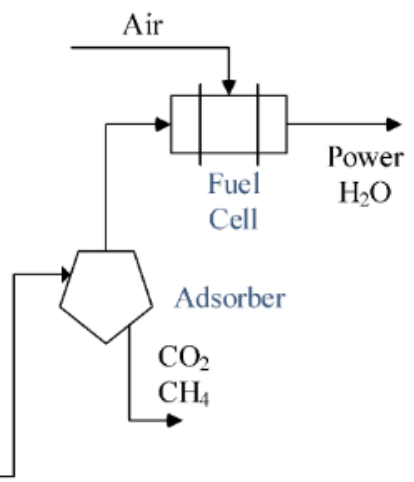

$\mathrm{H}_{2}$ stream free of $\mathrm{CO}$

Figure 1. 

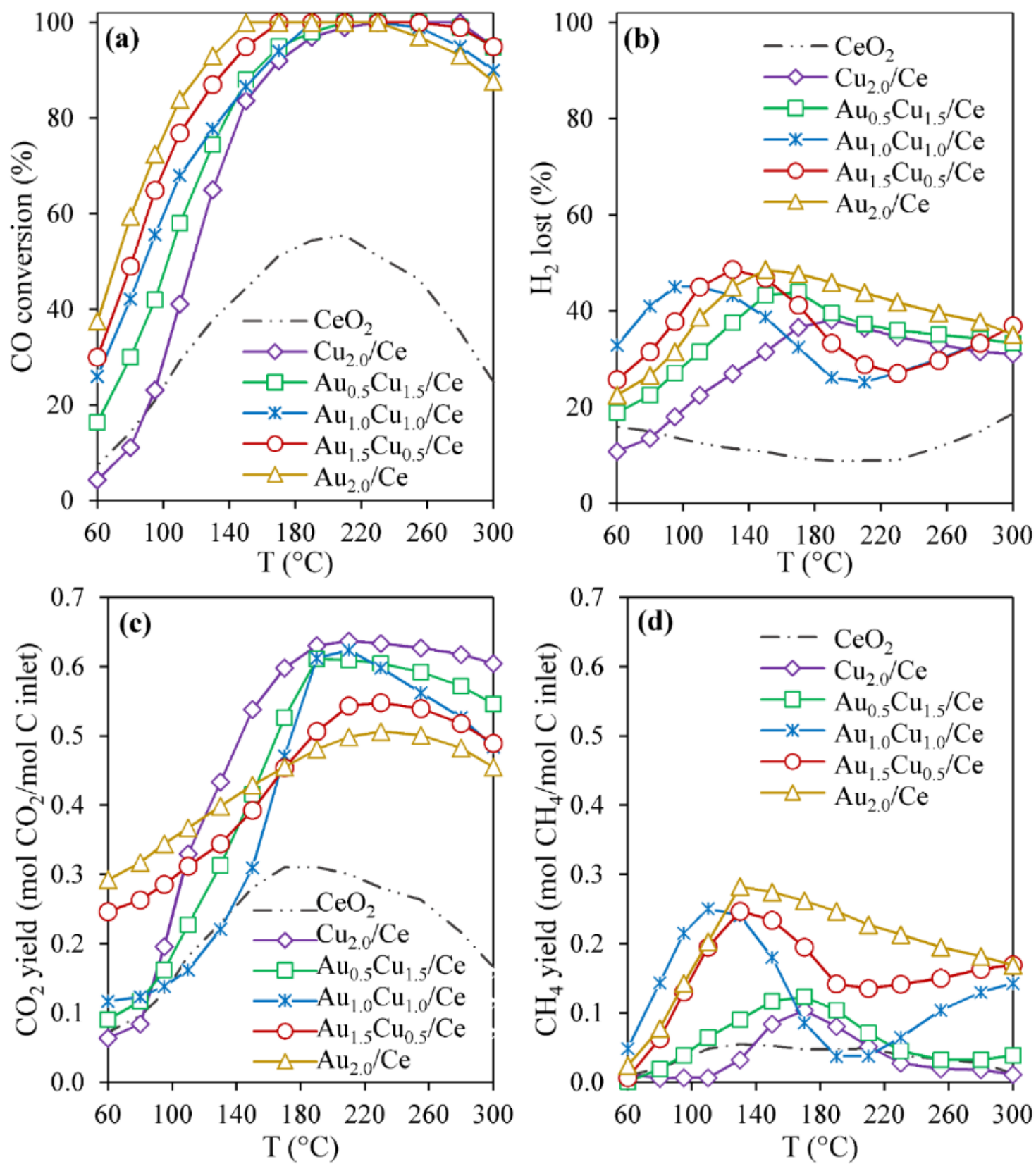

Figure 2. 

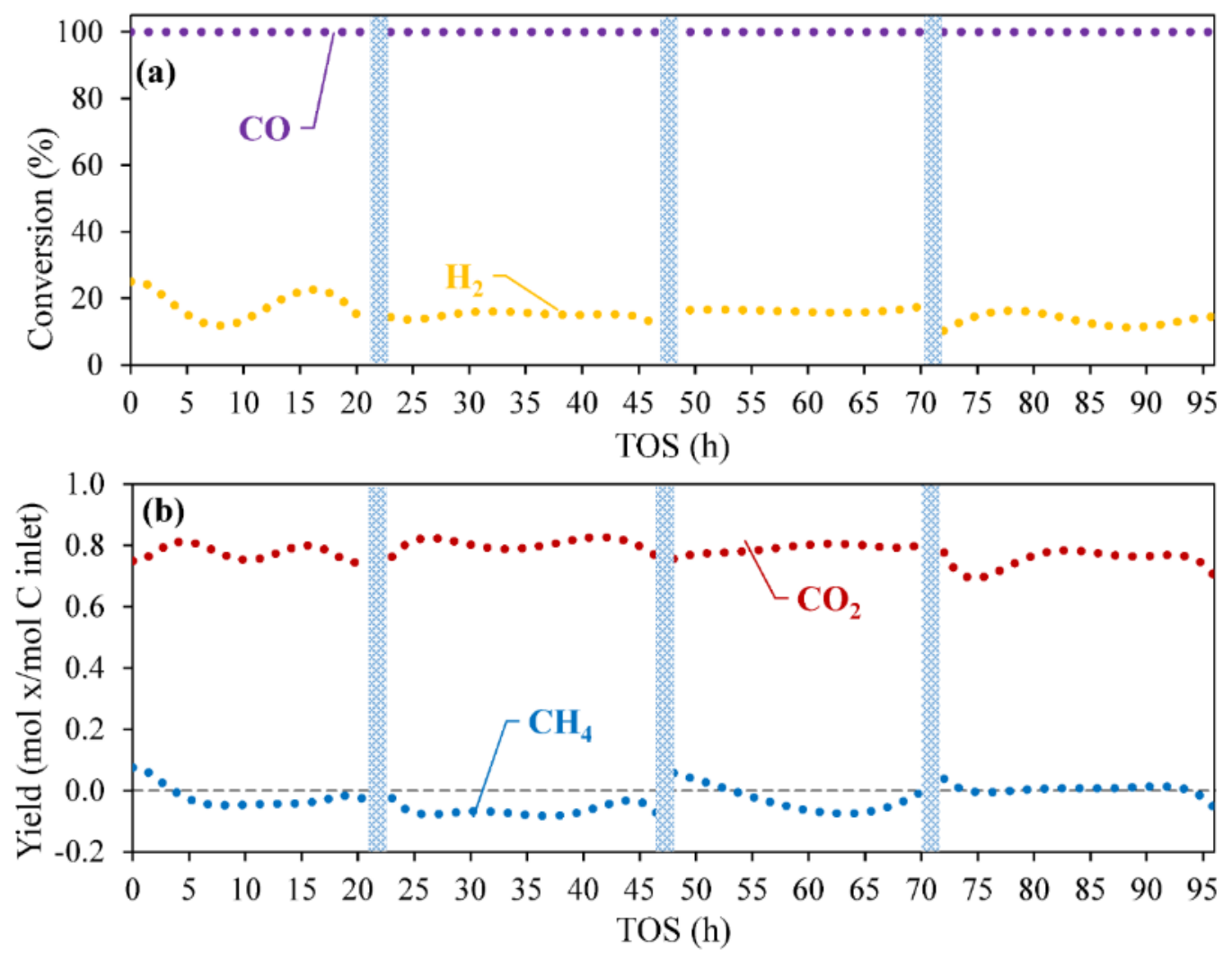

Figure 3. 
$\mathrm{CeO}_{2}$

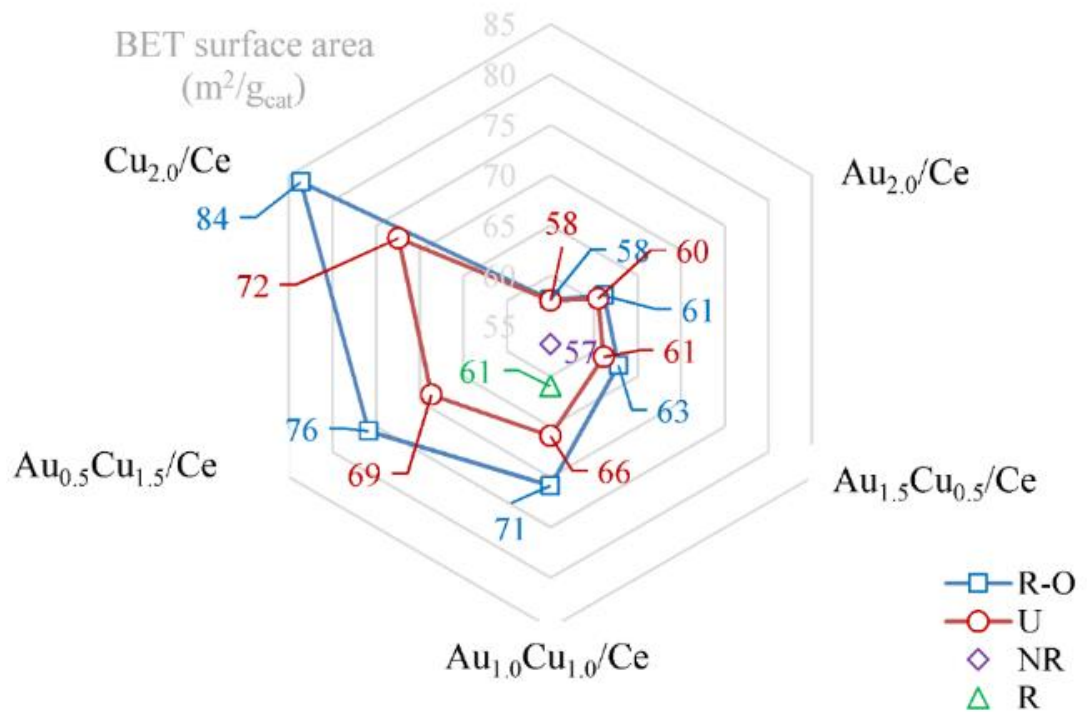

Figure 4. 

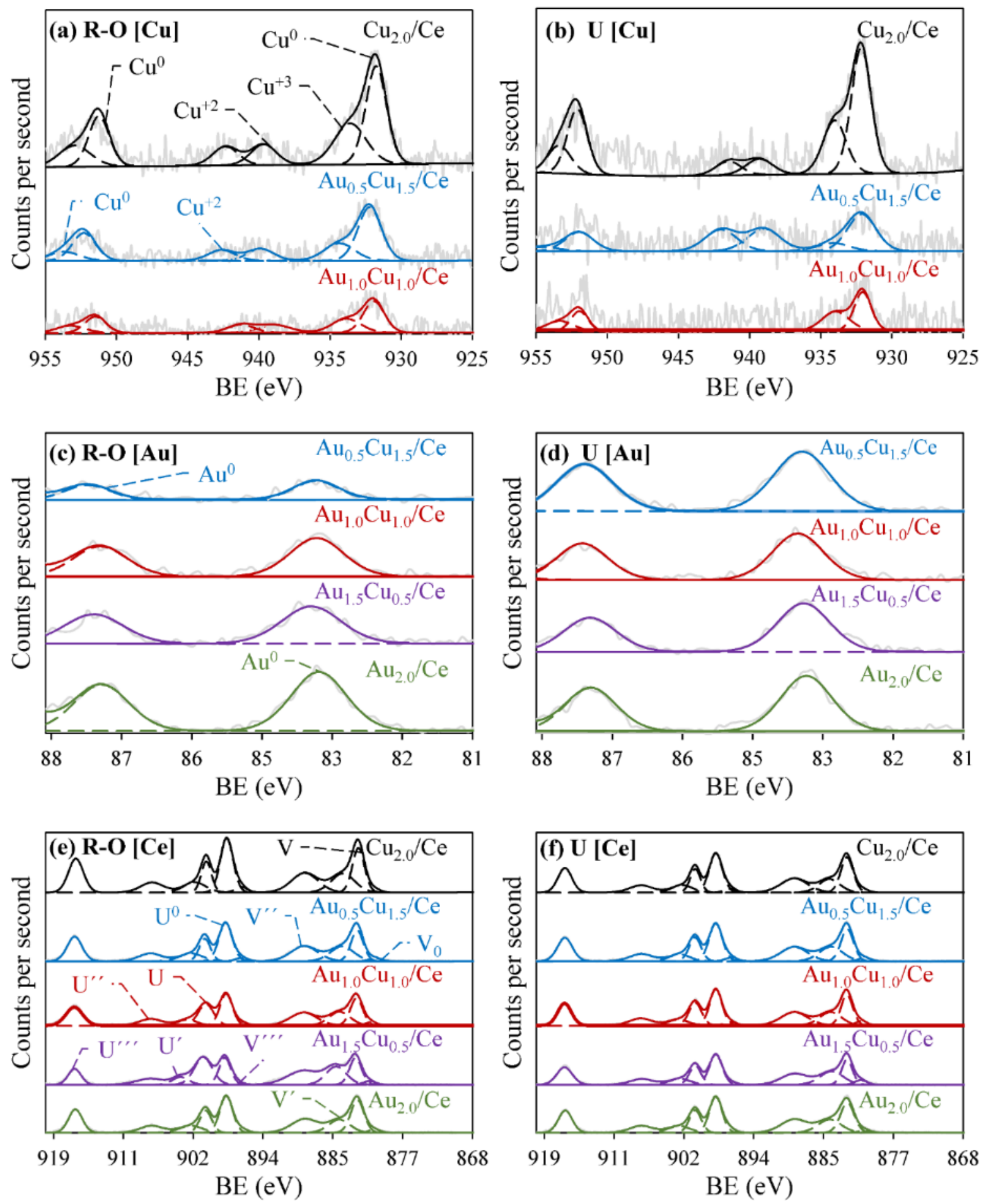

Figure 5. 

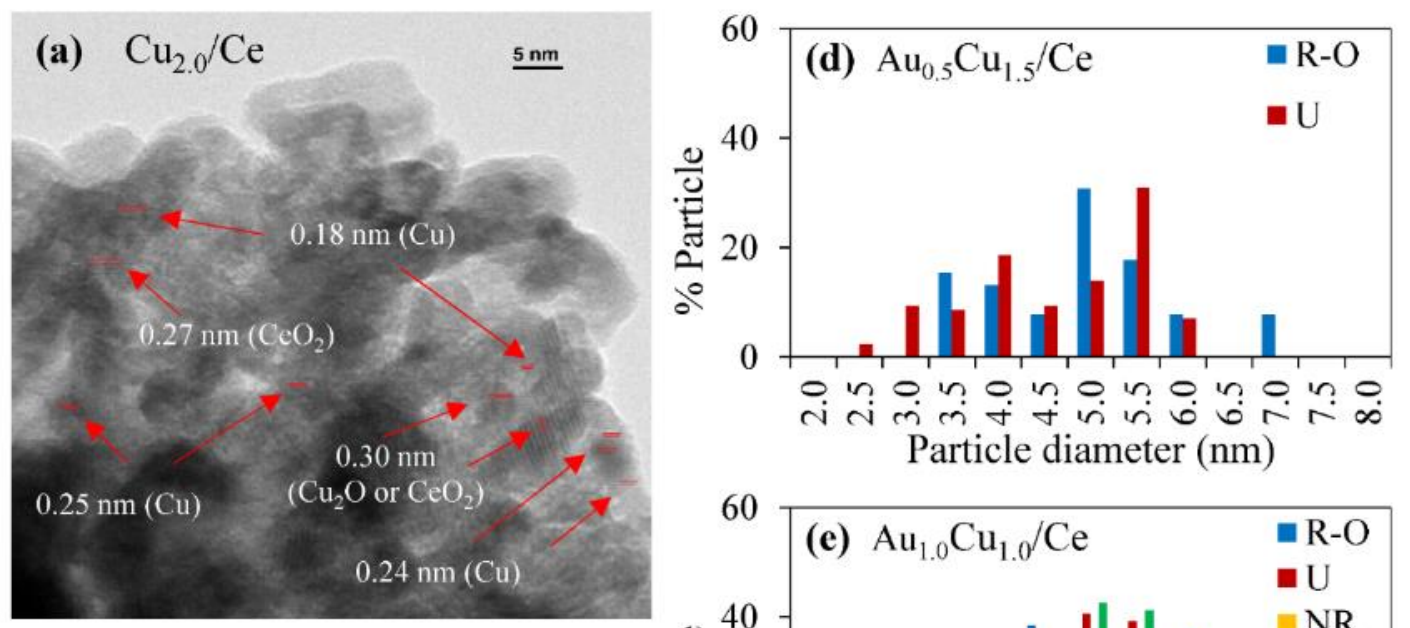

Particle diameter (nm)
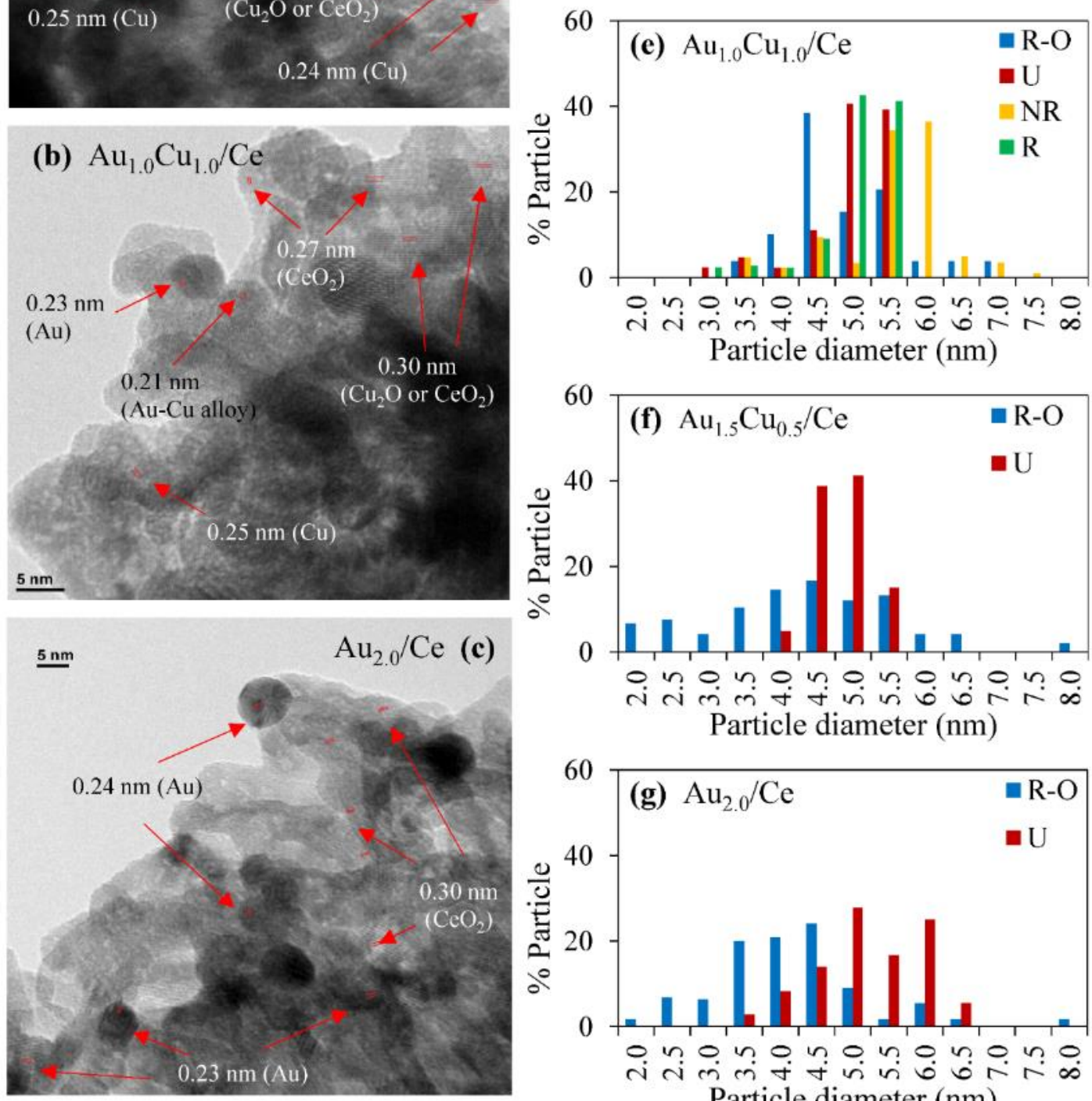

Particle diameter (nm)

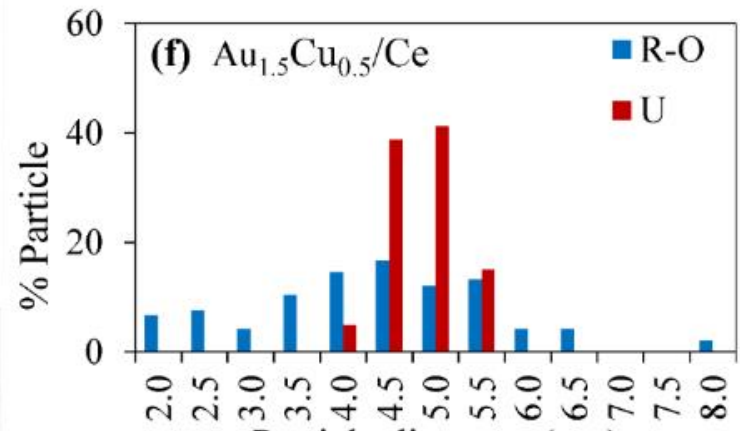

Particle diameter (nm)

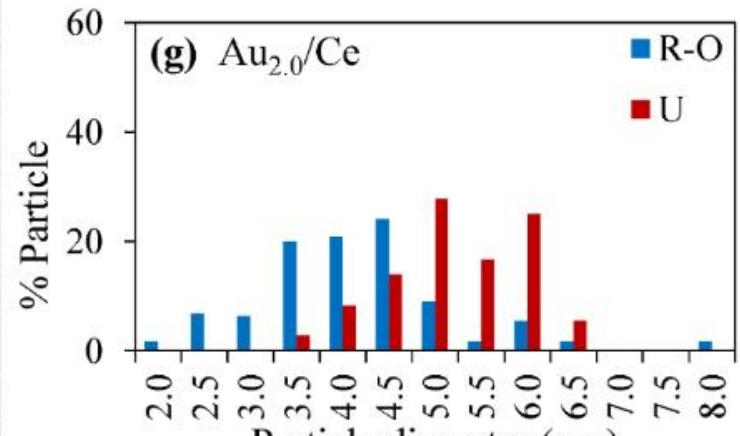

Particle diameter (nm)

Figure 6. 